\title{
Links between Insulin Resistance, Lipoprotein Metabolism and Amyloidosis in Alzheimer's Disease
}

\author{
Ian James Martins ${ }^{1,2,3 *}$, Rhona Creegan ${ }^{1,2}$ \\ ${ }^{1}$ Centre of Excellence in Alzheimer's Disease Research and Care School of Medical Sciences, Edith Cowan \\ University, Joondalup, Australia \\ ${ }^{2}$ School of Psychiatry and Clinical Neurosciences, The University of Western Australia, Nedlands, Australia \\ ${ }^{3}$ McCusker Alzheimer's Research Foundation, Holywood Medical Centre, Nedlands, Australia \\ Email: ${ }^{*}$ i.martins@ecu.edu.au
}

Received 23 April 2014; revised 5 June 2014; accepted 24 June 2014

Copyright (C) 2014 by authors and Scientific Research Publishing Inc.

This work is licensed under the Creative Commons Attribution International License (CC BY). http://creativecommons.org/licenses/by/4.0/

(c) (i) Open Access

\section{Abstract}

The origins of premature brain aging and chronic disease progression are associated with atherogenic diets and sedentary lifestyles in Western communities. Interests in brain aging that involves non alcoholic fatty liver disease (NAFLD), the global stroke epidemic and neurodegeneration have become the focus of nutritional research. Atherogenic diets have been linked to plasma ceramide dysregulation and insulin resistance actively promoting chronic diseases and neurodegeneration in developed countries. Abnormal lipid signaling as observed in chronic diseases such as hypothyroidism, obesity and diabetes is connected to stroke and neurodegenerative diseases in man. Lipids that are involved in calcium and amyloid betahomeostasis are critical to cell membrane stability with the maintenance of nuclear receptors and transcriptional regulators that are involved in cell chromatin structure and DNA expression. Western diets high in fat induce hyperlipidemia, insulin resistance and other hormonal imbalances that are linked to alterations in brain calcium and lipid metabolism with susceptibility to various chronic diseases such as stroke. Nutrition and food science research identifies dietary components and lipids to prevent hyperlipidemia and calcium dyshomeostasis connected to neuroendocrine disease by maintaining astrocyte-neuron interactions and reversing hormonal imbalances that are closely associated with NAFLD, stroke and Alzheimer's disease (AD) in global populations.

\section{Keywords}

Nutrition, Hyperlipidemia, Ceramide, Calcium, Neuron, Astrocyte

${ }^{*}$ Corresponding author. 


\section{Background}

Alzheimer's disease (AD) is the commonest form of dementia initially identified by Alois Alzheimer in 1906. It is a chronic, progressive neurodegenerative disease manifesting clinically as a disturbance in multiple higher functions of the brain, including memory, thinking, orientation, comprehension, calculation, learning capacity, language and judgment. It can also be accompanied by deterioration in emotional control, motivation or social behavior [1] [2]. In advanced stages, care by family members and caregivers is required to assist with daily living and ultimately an inability to recognize family members exacerbates the huge emotional burden. On average, the disease progresses from initial mild symptoms to severe dementia, with many sufferers requiring institutional care for many years.

Age stands as the greatest risk factor for AD and with an aging population a significant increase is predicted in the number of AD cases in both the developed and developing countries of the world [3] [4]. In Australia, approximately 300,000 people are suffering from dementia with this figure expected to reach to about 1 million by 2050 [3]. Current estimates put a direct cost of \$AUD3.2 billion to the healthcare system in Australia with a predicted increase of \$AUD6 billion within the next five years [5]. According to the Alzheimer's association in the United States unpaid care by family members and caregivers in 2009 represented \$144 billion. These alarming statistics emphasize the importance of gaining a greater understanding of the pathophysiology of AD with the aim of developing tests that will identify those at risk before the clinical hallmarks of AD manifest.

The type and amount of food eaten have a major influence on plasma lipid profiles [6]-[8] with dietary habits and nutritional status emerging as major contributors of any chronic degenerative disease. The well established risk factors for developing $\mathrm{AD}$ are elevated cholesterol and dyslipidemia, obesity, diabetes, hypertension, depression, cardiovascular and cerebrovascular disease, all of which are biochemically connected and are influenced by diet and possible nutrient deficiencies. Apart from dietary fatty acids being an energy generating nutrient, the amount and type of fat are important for determining disease risk due to the diverse functions of lipids in general; the structure and function of lipids are influenced by the diet. Intake of high saturated fat, trans-fatty acids, refined sugar, processed foods, and total calories [6] is strongly associated with the development of dyslipidemia, insulin resistance, obesity, diabetes, vascular disease and metabolic abnormalities; all risk factors for AD [9]-[11].

Neurodegeneration involves the accelerated aging of neurons leading to alterations in shape, size and stability of neurons. A link between premature aging, diet and nutrition is suggested with nutrigenomic research uncovering possible mechanisms such as epigenetic modifications that demonstrate the interaction between genes and environment. This includes various lipids species that influence calcium homeostasis and gene expression affecting cell survival [12]-[20]. Dietary modifications may help reduce the effects of metabolic dysfunction and associated endocrine abnormalities and lessen the global impact of chronic diseases such as diabetes, stroke, cardiovascular disease and neurodegenerative conditions, including Parkinson's disease (PD) and AD. Amyloid plaques are a characteristic feature of $\mathrm{AD}$ and contain aggregates of amyloid beta $(\mathrm{A} \beta)$, a $4 \mathrm{kDa}$ peptide of 39 43 amino acids normally found in the brain, albeit at low concentrations [21] [22]. Cholesterol and other lipids play a major role in $\mathrm{A} \beta$ metabolism and abnormal lipid metabolism is emerging as a key feature of AD pathology [23]-[25], with AD related changes in brain lipid composition reported [26].

Additionally abnormalities in various lipoproteins such as low density lipoprotein (LDL), high density lipoprotein (HDL) and their sub-classes are reportedly linked to AD [27]-[29]. Lipids in the nervous system also show enormous structural diversity and studying abnormal lipid profiles and levels of individual species may lead to a greater understanding of AD pathology. It is evident that many neurological disorders involve a complex interaction of proteins and lipids, which lead to the increased formation of abeta deposits [30]. A key development in the study of lipids and neurodegenerative disease has been in the advancement of technologies utilized in lipidomic research. These tools are leading to a greater understanding of $\mathrm{AD}$ and other conditions involving altered lipid metabolism, such as cardiovascular disease and diabetes and may facilitate the identification of disease biomarkers [31].

\section{Metabolic Dysfunction Increases Ceramide Levels with Amyloidosis}

In recent years numerous reports have highlighted the strong relationship between dementia and metabolic disorders such as dyslipidemia, obesity, diabetes, cardiovascular disease and hypertension (reviewed in [32]-[37]). While the mechanisms that underpin this association are beyond the scope of this review, it is important to em- 
phasize that the above conditions rarely occur in isolation, and the complex network of metabolic dysfunction which occurs in these conditions has been shown to influence many aspects of AD pathogenesis and neurodegeneration. For example, insulin is required for blood glucose regulation in the periphery and the brain. When peripheral insulin resistance (IR) develops metabolic dysfunction occurs and brain insulin signaling is altered affecting glucose utilization, $\mathrm{A} \beta$ and tau pathology, vasculature, mitochondrial function, inflammation, oxidation, neuronal maintenance and plasticity [32] [38]-[42].

Due to the integrated nature of the endocrine system virtually all hormones are likely to have some influence on lipid metabolism and therefore influence a myriad of cellular functions. The literature has many reports and studies into the effects of hormones on AD with virtually all known metabolic hormones being involved including insulin, thyroid, cortisol (and other non-sex steroids), growth hormone, leptin, ghrelin and adiponectin [43]-[45]. Insulin has a major influence on peripheral plasma lipid profiles such as very low density lipoproteins (VLDL), LDL and HDL and when insulin resistance is present such as in obesity the increased circulating free fatty acids (FFA) released from increased adipose tissue lipolysis eventually lead to increased hepatic VLDL secretion with disturbed cholesterol metabolism associated with increased amyloid burden [46].

A neurodegenerative cycle consisting of AD pathogenesis, insulin resistance and inflammation has often been described. The components of this cycle have elevated ceramide levels as a common factor (Figure 1), suggesting these toxic lipids alter lipoprotein composition and may represent the link between pieces of the AD puzzle [47] [48]. Emerging evidence suggests an association between insulin resistance and ceramide where toxic ceramides may be the intermediate that links excess dietary saturated fatty acids and inflammatory cytokines with insulin resistance [48].

In obesity ceramide metabolism is abnormal with the release of various sphingolipids and their metabolites from adipose tissue [49]-[55]. In both rodent obese models and in man plasma levels of various ceramide species have been shown to be elevated. Sphingosine-1-phosphate (S1P), a break down product of ceramide has been shown to associate with various lipoproteins and albumin in human plasma and regulate receptor lipoprotein interactions when abnormal lipoprotein metabolism occurs [55]-[57]. Interaction of S1P with other blood components such as platelets indicates lipoprotein abnormalities [58]-[62]. Changes in AD plasma also include platelet abnormalities where abundant amounts of S1P are stored. The early activation of platelets in insulin resistance and obesity releases $\mathrm{A} \beta$ into the periphery and the CNS with previous studies indicating the major involvement of platelets in $\mathrm{A} \beta$ release as a major source of the peptide in the circulation. In obese individuals platelet dysfunction [62] [63] S1P and A $\beta$ may also be relevant to $\mathrm{A} \beta$ homeostasis in $\mathrm{AD}$ [64] [65].

Abnormal ceramide metabolism in obesity and AD is important to the ceramide-cholesterol membrane interactions which can result in an imbalance in sphingolipid-cholesterol ratio in the cell membranes. Cellular ceramide accumulation alters a number of signal transduction events with marked shift in cellular bioenergetics with the progression of metabolic disease in the liver, heart and brain with particular relevance of insulin resistance and AD. Lipidomic profiling of plasma ceramide [66]-[69] has become important with ceramide levels associated with hepatocellular apoptosis (NAFLD), abnormal insulin synthesis and inflammation with ceramide now referred to as a cardiotoxin with lipotoxic cardiomyopathy [66]-[69]. Ceramide levels have been shown to be increased in the plasma, CSF and brain of AD individuals with abnormal sphingolipid metabolism linked to the metabolic syndrome and impairment of $\mathrm{A} \beta$ generation and degradation in $\mathrm{AD}$ [70]-[76].

The link between AD and lipid metabolism was firmly established when the APOE $\varepsilon 4$ genotype was identified as a major risk factor for $\mathrm{AD}$ [77]. In humans the apoE gene is located on chromosome 19q13.2 [78] and encodes for a 299 amino acid protein of which has three isoforms; $\varepsilon 2, \varepsilon 3$ and $\varepsilon 4$, resulting from the substitution of a cysteine with an arginine residue at codons 112 and 158 [79] [80]. Despite the amino acid difference at only one or two codons, the risk of developing various diseases is quite significant due to the conformational change and the influence this has on binding capacity [81] [82]. The following table (Table 1) shows allele frequencies in Caucasian and Australian populations and their influence on disease risk: It is estimated that being homozygous for $\mathrm{APOE} \varepsilon 4$ increases the risk of developing $\mathrm{AD}$ by the age of 75 by ten to thirty times compared to non-carriers of $\mathrm{APOE} \varepsilon 4$. $\mathrm{APOE} \varepsilon 2$ appears to be protective in terms of risk even when present with $\mathrm{APOE} \varepsilon 4$.

Apolipoprotein E (apoE) is an essential lipid transporter and component of triglyceride rich particles, such as chylomicrons and VLDL with cholesterol metabolism of chylomicron remnants and LDL regulated in an isoform-dependant manner via the LDL receptor family [24] [25]. In recent years the understanding of the interaction between apoE, lipids and $\mathrm{A} \beta$ has been predicted lipids as key components of membranes, providing an environment conducive for fluidity, ion permeability and regulating trafficking and proteolytic activity of the 


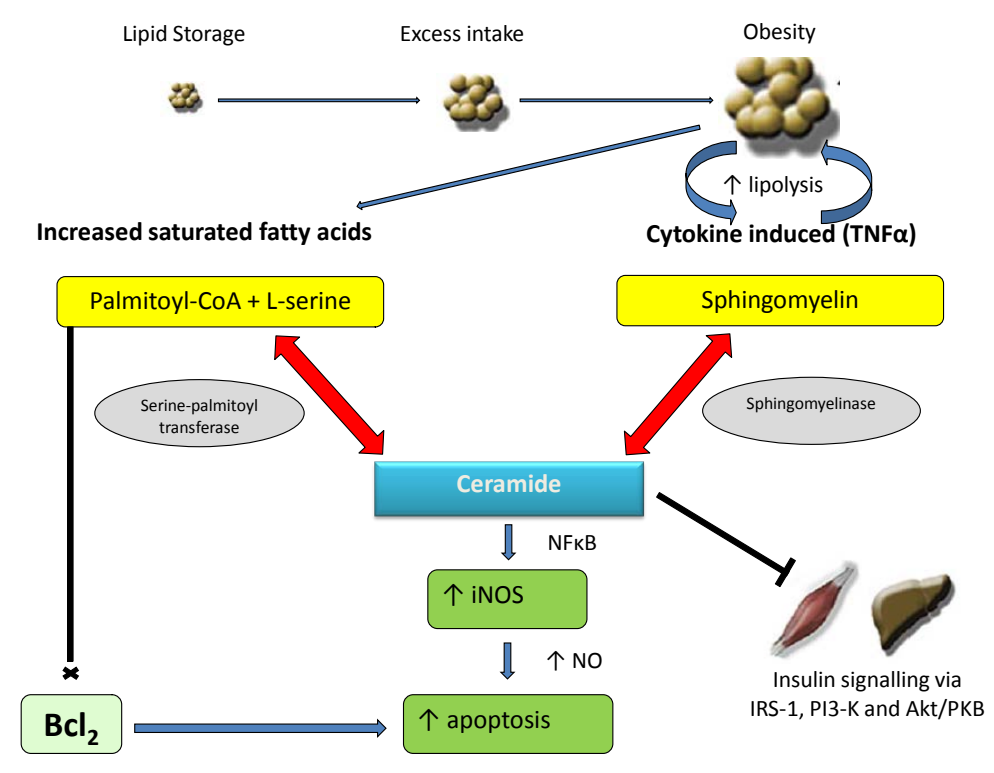

Figure 1. Ceramides - the toxic intermediate linking metabolic dysfunction, inflammatory cytokines and insulin resistance. When adipose tissue exceeds its storage capacity, adipokines increase inflammation which increases ceramides. This inhibits insulin signaling further increasing lipolysis and increasing the release of fattyacids for ceramide synthesis. Ceramide promotes apoptosis and the elevated saturated fatty acids inhibit the $\mathrm{Bcl}_{2}$ of anti-apoptotic proteins.

Table 1. ApoE gene frequency and disease risk [84]-[89].

\begin{tabular}{ccc}
\hline Genotype & Allele Frequency & Disease Association \\
\hline $\mathrm{APOE} \varepsilon 2\left(\mathrm{Cys}^{112} \mathrm{Cys}^{158}\right)$ & $7 \%$ & $\uparrow$ and $\downarrow$ risk for atherosclerosis [81] and $\uparrow$ risk for Parkinson’s Disease [83] \\
$\mathrm{APOE} \varepsilon 3\left(\mathrm{Cys}^{112} \mathrm{Arg}^{158}\right)$ & $79 \%$ & Considered neutral \\
APOE $\varepsilon 4\left(\mathrm{Arg}^{112} \mathrm{Arg}^{158}\right)$ & $14 \%$ & $\begin{array}{c}\uparrow \text { risk for atherosclerosis, AD, cognitive impairment, } \downarrow \text { hippocampal volume, faster } \\
\text { progression of multiple sclerosis, cerebrovascular disease and sleep apnea [84]-[91] }\end{array}$ \\
\hline
\end{tabular}

key membrane-bound proteins including (amyloid precursor protein) APP, ( $\beta$-site APP cleaving enzyme) BACE and $\gamma$-secretase involved in $\mathrm{AD}$ [24] [25]. Lipid rafts are domains within the plasma membrane bilayer consisting of cholesterol, glycosphingolipids and protein receptors. APP clusters in cholesterol-rich lipid rafts of neurons, astrocytes and microglia [92] [93]. These specialized regions compartmentalize cellular processes and act as organizing centers for assembly of signaling molecules. Rafts also influence membrane fluidity and are involved with membrane protein and receptor trafficking and the regulation of neurotransmitters [94].

Increased cellular ceramide levels regulate cellular cholesterol levels with effects on APP-Abeta processing [24] [25]. A $\beta$ is produced by cleavage of APP and APP can be processed by two different pathways a nonamyloidogenic pathway by $\alpha$-secretase or the amyloidogenic pathway by BACE [24] [25]. In both cases initial cleavage is followed by an additional cleavage by $\gamma$-secretase [95]-[97]. $\alpha$-secretase cleaves within the A $\beta$ domain of APP liberating a soluble APP fragment (APPs $\alpha$ ) which precludes the formation of A $\beta$ which has neurotrophic and neuroprotective properties [95]. The immediate precursor to $\mathrm{A} \beta$ is the C-terminal domain of APP called C99, which is the product of BACE cleavage of APP and has an affinity for cholesterol binding. Localisation of APP/C99 is therefore directed to the cholesterol rich rafts, where the BACE and $\gamma$-secretase are concentrated, thereby increasing amyloidogenic processing of APP [95] [98]. BACE has been shown to be stabilised by ceramides and therefore increased ceramides may promote amyloidogenic processing of APP [99] [100]. Furthermore S1P has been shown to adjust BACE activity in neurons with inhibitors of sphingosine kinase as targets for prevention of neurodegeneration in $\mathrm{AD}$ [101] [102].

In the brain apoE has been shown to be essential for ceramide metabolism and nerve sprouting and in these apoE knockout mice plasma lipoproteins were enriched in sphingomyelin [103] [104]. Individuals with neuro- 
pathologic changes of $\mathrm{AD}$ and the apoE4 isoform are associated with abnormal sterol and sphingolipid biochemistry [105]. However the apoE4 isoform in normal brain tissue was not associated with perturbed sterol or sphingolipid metabolism and indicated that the abnormal liver ceramide metabolism may override apoE4 related brain events with promotion of insulin resistance in AD individuals [105].

\section{Lipoprotein Metabolism, Phospholipid Transfer Protein, Insulin Resistance and AD}

Lipoproteins are complexes of proteins and lipids that solubilize lipids so they can be transported in the circulation between tissues. Lipoproteins are synthesized in the intestine from dietary lipids or in the liver from endogenous lipids and can also be remodeled from precursor lipoproteins under the influence of various metabolic signals. Lipoproteins have generally spherical structures typically consisting of a neutral lipid core of cholesteryl esters and triglycerides and a surface layer of phospholipids, unesterified cholesterol and various apolipoproteins. These apolipoproteins not only solubilize the lipids but also act as ligands for cell surface receptors and cofactors for plasma enzymes. High LDL, VLDL and low HDL are known risk factors for vascular disease, diabetes and AD [106]-[108] and dyslipidemia has been shown to be more prevalent in AD patients with BBB impairment [109].

Lipoproteins are dynamic with constant modification by the action of enzymes, lipid transfer and apolipoprotein (apo) exchange. This ensures specific lipid delivery to different tissues. Phospholipid transfer protein (PLTP) plays a key role in HDL remodeling and redistribution of ceramide to denser HDL may facilitate rapid transport across the BBB to brain cells in AD (Figure 2). The physiological relevance of PLTP is significant in PLTPdeficient mice, which demonstrate a total absence of PL transfer from VLDL to HDL and markedly reduced PLTP and HDL levels [110] [111]. PLTP is a non specific lipid transport protein and is known to transport amphiphilic molecules including $\mathrm{A} \beta$, lipopolysaccharides/diacylglycerol to HDL [112]-[114]. PLTP deficient mice demonstrate A $\beta$ toxicity and memory deficits [115] [116]. PLTP also facilitates the transport of other lipophilic substances such as $\alpha$-tocopherol [117]. It is important in preventing LDL oxidation and subsequent uptake of oxidized LDL by vascular endothelium [118]. PLTP deficiency in the brain has been shown to result in reduced $\alpha$-tocopherol and an increase in oxidative injury, leading to neurological dysfunction [117] [118]. This suggests that PLTP is a local transporter of $\alpha$-tocopherol and may transport $\alpha$-tocopherol across the BBB. A major function of PLTP is to maintain the plasma sub species of HDL [119] [120] and the CNS HDL like lipoproteins [121] [122]. Most studies have been done in relation to atherosclerosis and metabolic disease and are contradictory with some finding higher PLTP activity levels and increased risk of disease [121]-[123] and others finding lower levels associated with disease [124] [125]. The protective or disease promoting effects of PLTP remain unclear as HDL cholesterol levels vary in response to PLTP gene overexpression or deficiency [126] [127]. It may be that the effect of PLTP on disease may depend on the background lipid profile, metabolic landscape, co-morbidities, medication use and dietary considerations.

In addition to PLTP in plasma, cholesterol ester transfer protein (CETP) is also involved in HDL speciation [128]. CETP is secreted mainly by the liver and circulates in plasma mainly bound to HDL. It redistributes cholesteryl esters from HDL to TG rich lipoproteins (CM and VLDL) and transfers TGs from VLDL and CM to LDL and HDL [128]. PLTP facilitates the transfer of phospholipids from TG rich lipoproteins to HDL and together with CETP is important in reverse cholesterol transport by modifying the size and function of HDL (Figure 2).

As previously mentioned insulin resistance is associated with elevated plasma ceramides which may also influence lipoprotein metabolism and amyloidogenic processing (Figure 3) with the central role of the liver in release of VLDL and LDL ceramide into the bloodstream. The elevation in plasma ceramides influence plasma lipoprotein toxicity which adversely affects intracellular processes and induces cell apoptosis [129] [130]. Within cells ceramide transport to the golgi apparatus is regulated by the ceramide transport protein [131] with elevated saturated ceramide levels or metabolites involved in membrane fluidity or organization and regulation of PLTP activity in sphingomyelin transport to cells and lipoproteins [132]-[136].

In the brain glial cells and astrocytes support function and promote survival of neurons with the central role of the astrocyte in the metabolism of neuronal $\mathrm{A} \beta$ homeostasis with other astrocyte functions that include production of apoE, production of neurotrophic factors, angiogenesis, supply of glutathione (oxidative stress) and energy substrates, modulator of xenobiotic toxicity, maintenance of neuronal calcium homeostasis, lipid and cho- 
Peripheral Cell

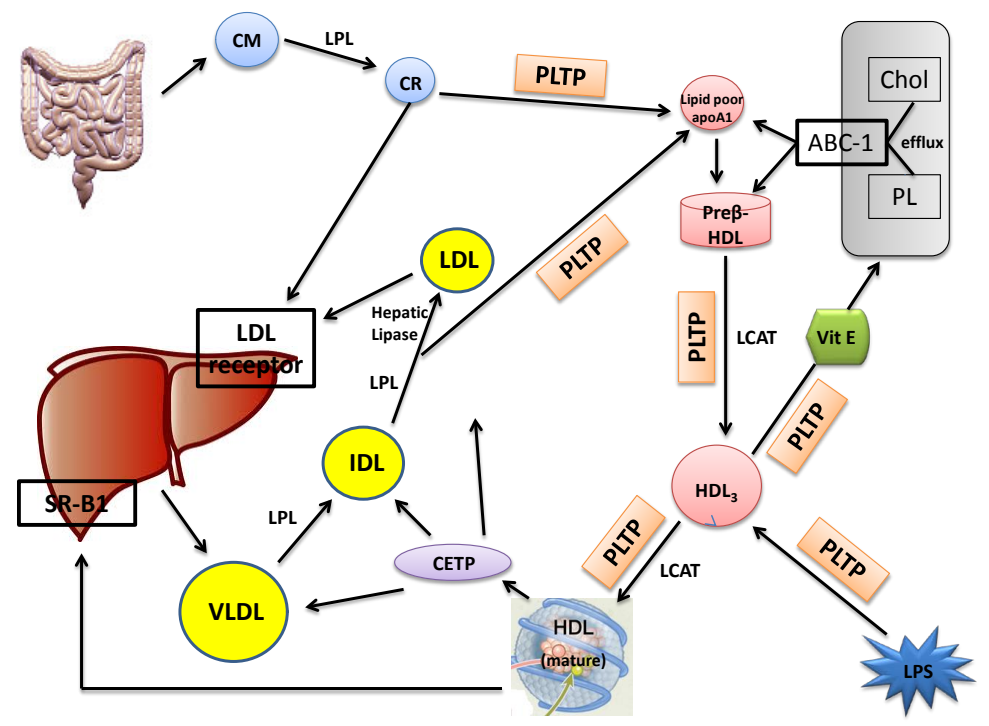

Figure 2. Lipoprotein metabolism and lipid transfer proteins (PLTP and CETP) with effects on dietary lipoproteins (chylomicrons), hepatic derived lipoproteins (VLDL, IDL, LDL) andHDL lipoproteins.

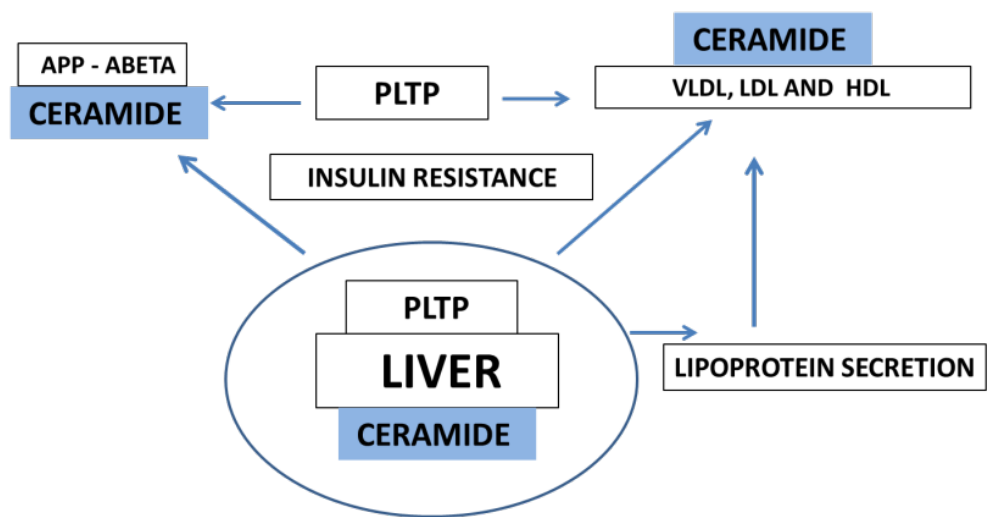

Figure 3. Effects of insulin resistance on PLTP, hepatic ceramide lipoprotein secretion and on ceramide APP-A $\beta$ processing.

lesterol synthesis (Figure 4) [137]-[146]. Astrocytes maintain cholesterol homeostasis in neurons by transport of cholesterol containing lipoproteins via apoE [147]-[150] with ATP binding cassette transporter 1 (ABCA1) involved in cholesterol efflux to lipoproteins such as HDL with S1P release [151]. Production of apoE by astrocytes is central to neuron cholesterol metabolism with apoE closely connected to activation of PLTP activity and in diabetes changes in apoE levels have been associated with PLTP activity [152] [153]. ApoE-PLTP interactions involve ABCA1 with the critical binding of PLTP to ABCA1 dependent cholesterol efflux [154]. Furthermore, astrocytic DAG has been shown to modulate PLTP activity and A $\beta$ homeostasis with DAG involved in astrocyte ATP release and adjustment of neuron excitability [155]-[158].

Peripheral lipid disturbances that involve ceramide are closely linked with to BBB disorders that jeopardize astrocyte-neuron interactions that may cause neuron cholesterol overload, $\mathrm{A} \beta$ dyshomeostasis with damage to astrocytes by neuron A $\beta$ oligomers [159]-[162]. Ceramide has been shown to stimulate cholesterol efflux and involve increases in membrane ABCA1 activity without apoE-PLTP involvement [163] [164]. The peripheral sink $\mathrm{A} \beta$ hypothesis indicates that the transport of $\mathrm{A} \beta$ oligomers across the $\mathrm{BBB}$ is regulated by astrocytes (Figure 4) and transported from the central nervous system to the periphery for rapid metabolism by the liver [165] and this 


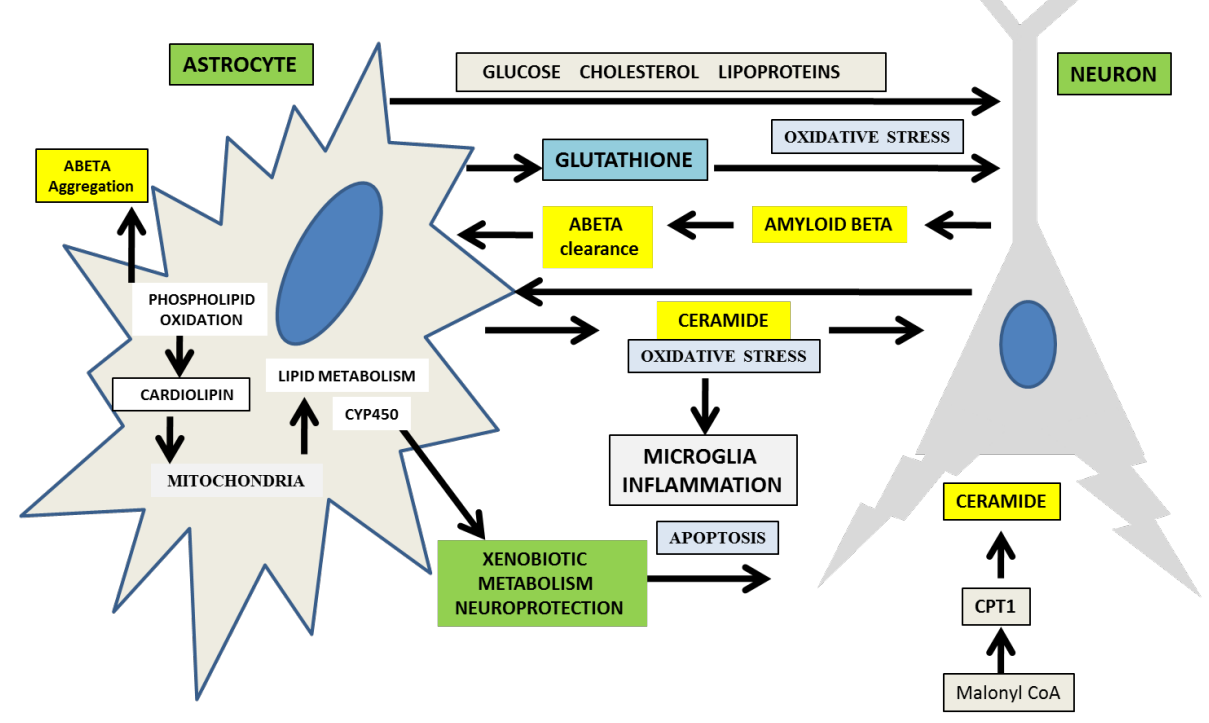

Figure 4. Astrocytes are involved in neuron amyloid beta clearance, cholesterol homeostasis and xenobiotic metabolism.

process in metabolic dysfunction involves abnormal ceramide metabolism and AD. Interests in high fat diets with endocrine dysfunction and NAFLD override any apoE isoform effects with influences in brain lipid metabolism [43] [166] with the involvement of astrocyte disease possibly responsible for the brain cholesterol and $\mathrm{A} \beta$ dysregulation as found in AD [137] [138] [143]. Lipid mediators exert numerous effects on cellular function. These effects involve astrocyte modulation of enzyme activity, neural cell differentiation, immune responses, inflammation, oxidation, cell migration, mitogenesis and apoptosis and therefore imbalances in any of these mediators would predictably contribute to AD pathology [167].

\section{Lipids Influence Lipoproteins, Cell Membrane and Nuclear Receptors with Chronic Disease Progression}

Intake of saturated and trans fatty acid is positively correlated with increased cholesterol levels and unfavorable shifts in LDL:HDL ratios [168]-[170]. Excess palmitic acid can also upregulate ceramide production, which is considered a major contributor to hypercholesterolemia, insulin resistance and obesity [45] [171]. The most commonly consumed fatty acids are myristic (14:0), palmitic (16:0), stearic (18:0), oleic (18:1) and linoleic (18:2). Each of these fatty acids "affects" plasma cholesterol levels differently due to their impact on the LDL receptor, whose activity is regulated by the sterol content of the cell viasterol regulatory element-binding protein(SREBP) [9] [11]. Dietary fatty acids and cholesterol can increase the sterol regulatory pool by their effects on the hepatic enzyme acylCoA-cholesterol acyl transferase (ACAT) [172] [173]. Saturated fatty acids such as palmitic acid partially inhibit cholesteryl ester (CE) formation by ACAT, therefore increasing the amount of free cholesterol. In liver cells enriched with monounsaturated fats (MUFA) and polyunsaturated fats (PUFA) ACAT activity is increased as it is a preferred substrate and CE formation is promoted [173]. Furthermore, ceramide decreases SREBP post transcriptional regulation and these effects are independent of intracellular cholesterol levels [174].

Dietary trans fatty acids are known to contribute to dyslipidemia and associated increased disease risk [175] have been associated with brain aging and impaired cognition [176] [177]. Atherogenic diets (Figure 5) increase membrane cholesterol and ceramides that influences membrane fluidity with altered APP-A $\beta$ processing and their tendency to promote abeta aggregation with relevance to chronic disease and neurodegeneration.

Most naturally occurring fatty acids have double bonds in a cis configuration which allows the chain to bend. The trans bond imparts a rigid structure which is similar to that of saturated fatty acids and increased consumption from processed and fast foods can lead to dyslipidemia [175]. Trans fatty acids alter membrane fluidity and responses of various membrane receptors by their incorporation into membrane phospholipids. The effects on lipid metabolism are due to several mechanisms. Trans fatty acids alter the secretion, composition and size of apo- 


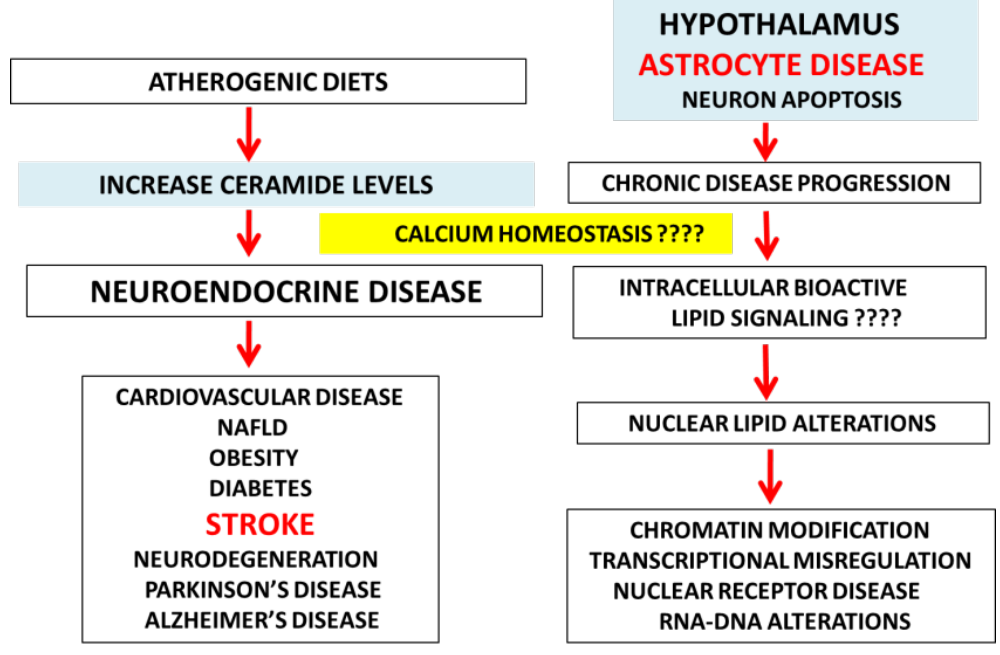

Figure 5. Atherogenic diets are closely associated with oxidative stress, lipid peroxidation with the generation of second messengers that promote chronic disease progression and neurodegeneration.

lipo-protein B-100 produced in the liver and increase the cellular accumulation and secretion of free cholesterol and cholesterol esters by the liver [178]. The effects on reducing HDL are associated with an increase in CETP with abnormal transfer of cholesterol esters from HDL to LDL and VLDL [179]. Additionally the fluidity, determined by the fatty acid at the sn-2 of PC is a major regulator of lecithin:cholesterol acyltransferase (LCAT), which is required for the formation of mature HDL. Trans fatty acids affect membrane fluidity and reduce LCAT activity [180] with effects on abeta aggregation and on important signaling lipidsin the membrane bilayer, lipid rafts and lipoproteins that are involved in the generation of second messengers (Figure 5).

As fatty acids act as ligands for nuclear receptors (Figure 5), such as sirtuin 1 (Sirt1), peroxisome proliferator activated receptors (PPARs), liver X receptor (LXR) and SREBP, regulation of gene transcription can be altered [181]-[184], directly modulating metabolic and inflammatory responses in the periphery and brain. Sirt1 are nicotinamide $(\mathrm{NAD}+)$ dependent histone deacetylases which are activated by cellular stresses to enhance cellular defense and repair pathways and to mediate adaptive responses to changing energy requirements. This is achieved by deacetylation and transcriptional control of numerous genes involved in lipid, glucose and $\mathrm{A} \beta$ metabolism [184]-[186]. Saturated fatty acids such as palmitic acids have been shown to inhibitSirt1 with the development of hepatic steatosis as observed in Sirt1 knockouts [187] [188]. Additionally Sirt1 has been closely linked to obesity and AD [189] and shown to regulate liver cholesterol metabolism and attenuate amyloidogenic processing of APP both in cell culture models and in transgenic mice [185] [186], suggesting a possible mechanistic link between saturated fatty acids, peripheral cholesterol/ceramide metabolism and AD pathology.

Brain aging associated with dyslipidemia and oxidative stress coupled with altered gene expression profiles delays DNA repair mechanisms that underlie aging, stroke [190] and neurodegeneration. The anionic glycerophospholipid phosphatidylserine and phosphoinositides are located in the chromatin and the regulation of chromatin structure, gene expression and transcription is determined by the nuclear lipids [191]-[194]. Inflammation and oxidative stress associated with hypercholesterolemia generate reactive chemical species with oxidation of membrane and nuclear lipids with chronic damage to DNA and RNA in astrocytes and neurons. Diets that accelerate inflammatory processes disturb the astrocyte-neuron interactions affecting neuron survival and synapse formation. Diets that stabilize neuronal membrane and nuclear lipids are important for the maintainance of astrocyte and neuron function and may slow disease processes associated with amyloidogenesis and also involved in neurodegeneration.

Epigenetic changes induced by alteration in nuclear lipids (Figure 5) change the expression of genes through transcription and other lipids such as diglycerides, phospholipids, cholesterol and cholesterol esters also determine chromatin structure [195]-[197]. High fat high cholesterol (HFHC) diets induce oxidative stress that accelerates lipid peroxidation of phospholipids and cardiolipin involved in nuclear stability and neuron proliferation [197]-[199] and also involved in A $\beta$ fibrillization. Additionally, sphingomyelin is involved in chromatin assem- 
bly and dynamics and different sphingolipid species have varying effects on nuclear domains, envelope and chromatin structure. Sphingomyelin and phosphatidylcholine are associated with cholesterol in the nuclear membranes but play different roles in nuclear lipid micro-domains. Different sphingolipid species are localized in various subnuclear domains, including chromatin, the nuclear matrix, and the nuclear envelope, where sphingolipids exert specific regulatory and structural functions [200]-[204]. Nuclear lipid peroxidation and altered gene profiles affect the delicate balance of lipid sensing in liver and brain [205] [206]. These altered brain gene expression profiles may involve the intake of high fat diets and affect the whole body lipid, calciumand glucose metabolism with disturbances in nuclear receptors (PPAR-sirtuin 1 complex, liver X receptors, sterol regulatory element-binding proteins, nuclear factor $\mathrm{\kappa B}$, farnesoid $\mathrm{X}$ receptor) [207]-[209] and membrane receptors such as G protein-coupled receptors (GPCR) involved in lipid and calcium homeostasis [210]-[213]. Furthermore in studies assessing the effects of HFHC diets in mice, dyslipidemia associated with altered brain lipids and NAFLD are possibly related to significant changes in enzymes involved with brain nuclear lipid signaling that generate second messengers derived from phospholipids such as the phosphoinostides, ceramide, glucosylceramide (GlcCer), sphingolipid metabolites and cannabinnoids involved in gene regulation that control a variety of cellular survival processes in the liver and brain [214]-[233]. In mice HFHC diets (Figure 5) increase oxidative stress and free radicals which alter various lipids [234] and show marked changes in brain cardiolipin content and acyl chain composition affecting neuron mitochondria and resulting in nuclear disturbances in these mice. Cardiolipin is bound to DNA with the component unsaturated fatty acyl residues involved in regulation of gene expression. Brain cardiolipin content decreases with aging and lipid peroxidation is responsible for the reduction or biosynthesis of cardiolipin content. Decreased cardiolipin content has also been found in NAFLD, cardiovascular disease, diabetes and neurodegenerative diseases and is also associated with mitochondrial dysfunction [235][239]. Furthermore alterations in ceramide levels in chronic diseases (Figure 5) that involve the induction of mitochondrial apoptosis also involve abeta oligomers that are involved in membrane pore forming or ion channel formation with entry of calcium into cells [240]-[242].

HFHC diets that induce an increase in sphinoglipid metabolites including S1P in the periphery and CNS may affect various astrocyte-neuron-endothelial interactions (Figure 6) and adversely affect BBB function. S1P binds to GPCR or S1P receptors and modulates or increases the activity of cytochrome P450 enzymes responsible for cholesterol and xenobiotic metabolism [243]-[245]. S1P and other second messengers may enter the nucleus and initiate cell-modifying processes without the GPCR leaving the plasma membrane [210] [211] [246][248]. Otherwise entry into the nuclear membranes of intact GPCRs or fragments that bind S1P directly initiate or regulate transcriptional events in the nuclear domain.

\section{Calcium, Lipids and Hormone Dysregulation Effect Astrocyte and Neuron Membrane Biology and Promote Amyloidogenic Pathways}

In developed countries chronic metabolic diseases that involve altered lipid metabolism and insulin resistance affect the neuroendocrine system which leads topremature aging in neurons that promotes $\mathrm{A} \beta$ protein aggregation. This contributes to astrocyte dysfunction and generates signals initiating neuronal death. In addition to abnormal insulin signalling, other hormone imbalances present in neuroendocrine disease affect lipid and calcium metabolism. Hormones (Figure 6) play an important role in the interactions between neurons, astrocytes, oligodendrocytes, microglia, endothelial cells and other cells in various regions of the brain and BBB.

Nutritional research identifies diets that reduce oxidative stress, hormone imbalances and dyslipidemia that adversely affect calcium-membrane lipid interactions have become important to the maintenance of premature brain aging and AD. Astrocyte stability appears to be influenced by diet which affects hormone and calcium balance and the levels of bioactive lipids. High fat diets and obesity in both rodents and man have been shown to promote astrocyte dysfunction which compromises neuronal survival and due to the effects on energy homeostasis increases the risk for obesity and other metabolic diseases [249]-[262]. Insulin resistance compromises astrocyte survival as insulin plays a role in the maintenance of astrocyte function. Diabetes and hyperglycemia lead to abnormal communication between neurons with the death of astrocytes [263]-[265]. Research into how blood lipids and hormone imbalances affect astrocyte lifespan and function is an active area of research and may contribute to the understanding of neurodegenerative processes that occur in disorders such as AD, PD and Hungtington's disease [266]-[271].

Lipid signaling between astrocytes, and microglia is essential for neuron survival and determine the senescence 


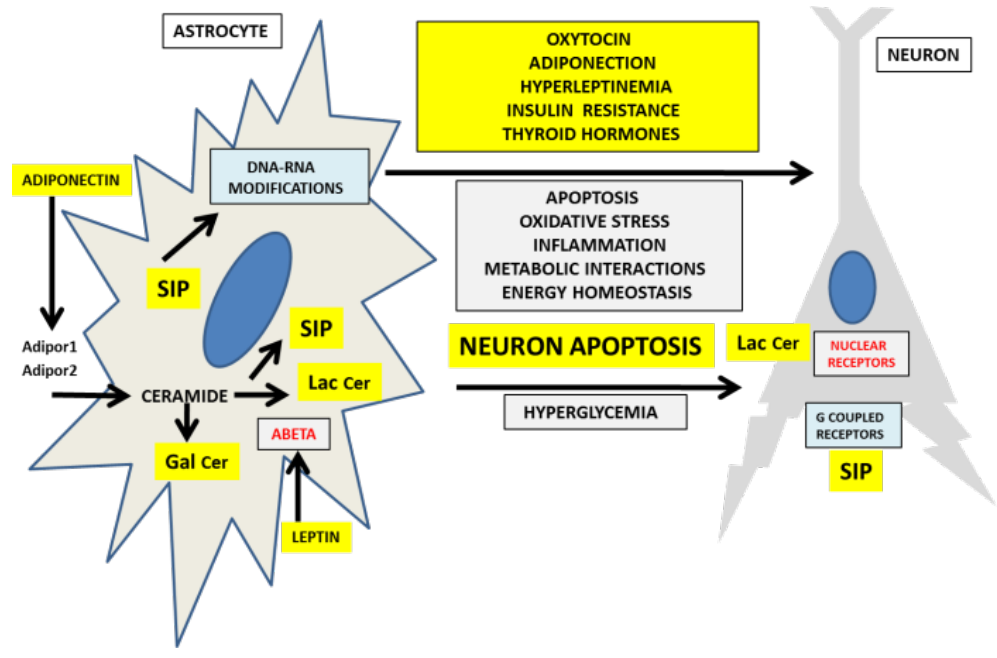

Figure 6. Peripheral metabolic hormones and bioactive lipids regulate astrocyte survival and oxidative stress with neuronal apoptosis.

of neurons. Lipids such as cardiolipin, anionic phospholipids and sphingolipids including ceramides not only affect astrocyte andmicroglia function but also influence neuron calcium homeostasis. Abnormal calcium homeostasis is linked to excitotoxicity and neuronal cell death and recent studies have shown that elevated calcium levels are linked to insulin resistance and diabetes [272]-[277]. Furthermore, metabolic disorders such as obesity and diabetes in which endocrine disturbances are present appear to promote bioactive lipid interactions affecting astrocyte function and neuron calcium homeostasis, which influences membrane function, nuclear lipids and cell receptors such as the GPCRs. Hormones binding to receptors such as the GPCRs in astrocytes result in signal transduction and are linked to a heterotrimeric $G$ proteinwhich alters the amount of astrocytic calcium released from endoplasmic reticulum (ER)and may result in altered neuron activity (Figure 6). Abnormalities in intracellular neuron calcium and lipid regulation are strongly linked to ER stress that accelerate protein aggregation disorders such as occurs in non-alcoholic fatty liver disease (NAFLD), diabetes and AD [278]-[282].

Lipids such as ceramide-1-phosphate, phosphoinositides, arachidonic acid (AA), docosahexaenoic acid (DHA), DAG and prostaglandin E2 have significant effects on intracellular calcium affecting calcium dysregulation in the ER and mitochondria leading to cell death [283]-[286]. Polyunsaturated fatty acids such as DHA and AA may have neuroprotective effects by regulation of phospholipase A2 activity with marked effects on astrocyte and neuronal calcium levels involved in ER stabilization in brain and peripheral cells [286]-[288]. Other bioactive lipids present in astrocyte and neuronal cell membranes such as endocannabinoids (Figure 6) and platelet activating factor (PAF) which participates in signaling cascades associated with calcium channels and calcium homeostasis may also play a role in neuroendocrine disease [289]. In diabetes, neurodegeneration and stroke [290] [291] PAF is being shown to contribute to the pathological processes by its influence on eicosanoid synthesis which participate in inflammatory and chronic neurological processes.

As previously stated obesity and diabetes lead to abnormal peripheral lipid metabolism and also involve disturbances in several hormones including triiodothyronine (T3), thyroxine (T4), leptin, adiponectin, and insulin [292]-[294]. In the brainhormones such as insulin, leptin, adiponectin, oxytocin, corticotropin releasing hormone (CRH) and thyroid hormones bind to extracellular receptors in astrocytes (Figure 6). Astrocytes play a central role in thyroid hormone metabolism in the brain and are responsible for uptake of thyroxine from the blood and its conversion to 3,5,3'-triiodothyronine. The supply of the biologically active form of thyroxine to neurons is important to neuron survival, neuritogenesis and synapse formation [295] [296]. Thyroid hormones, adiponectin and leptin have been shown to target the oxytocin neurons with control of body weight regulation and lipid metabolism [297]-[301]. Thyroid hormones have profound effects on adipokines, lipid metabolism and carbohydrate homeostasis with alteration in plasma lipids and zinc deficiency linked to hypothyroidism [302]. Other peripheral hormones such as cortisol are also associated with insulin resistance and dyslipidemia with hypothalamic CRH involved in its regulation and peripheral calcium homeostasis. This suggests that the existence of a complex network of hormones that regulate neuronal function involves calcium/energy homeostasis and is in- 
fluenced by nutrient status.

ApoE is an essential protein synthesized by astrocytes and is involved in peripheral lipid metabolism with various effects on neurons such as induction of endocytosis and neurotransmission mediated by calcium alterations [148] [149] [303]-[305]. Calcium alterations determine the conformation and therefore activity of the low density lipoprotein receptor (LDL r). The activity of the LDLr is linked to neuronal plasticity and cell proliferation [306]. In neurons physiological regulation of calcium influx and its associated second messengers affect contractile proteins that determine shape, size and positioning of cells [307] [308] and a number of neuron processes and circuits [309]. In cell membranes the distribution of lipid species in the lipid bilayer determines lipid asymmetry which influences numerous cellular functions [310] [311]. Calcium dysregulation alters this lipid asymmetry (Figure 7) which can lead to an imbalance of sphingolipids promoting apoptotic processes and cell death. The role of calcium homeostasis in membrane biology is particularly relevant to neurodegeneration as calcium modulates negatively charged lipids in membranes (Figure 7) such as phosphatidylinositol, phosphatidylserine and phosphatidyl 4, 5-bisphosphate and the subsequent release of lipid mediators [16]-[20].

The sphingomyelin-cholesterol interaction is the physicochemical basis for the formation of cholesterol/sphingolipid domains in plasma and cell organelle membranes [311]. Sulphatides, myelin specialized sphingolipids, have been shown to participate in ordered domain formation in cholesterol/phospholipid/sphingmyelin membranes (Figure 7) and thesesulphatides are influenced by the presence of $\mathrm{Ca}^{2+}$ in these membranes [312] [313]. Sulphatides are synthesized mainly in astrocytes and in AD the sulphatides are markedly decreased in the brain [314] [315]. In the brain apoE containing lipid particles, similar to HDL also contain astrocyte derived sulphatides [316] [317] and are essential for promoting neuron survival by maintenance of the neuron membranes. Alterations in apoE mediated sulphatide trafficking have been shown to deplete sulphatide in the brain, and CNS levels of sulphatide have been shown to be apoE isoform dependent, with the lowest levels observed with APOE $\varepsilon 4$ [25] [318]. Low sulphatide levels have also been associated with diabetes and insulin resistance [319] and sulphatides have been shown to control insulin secretion by modulation of ATP-sensitive K channel activity in rat pancreatic beta cells [320]. Sulfatides stimulate the calcium-sensitive, Kp channel (BKCa channel) [320] and direct calcium binding alter cellular membrane potentials which may be relevant to neurological dysfunction and $\mathrm{AD}$.

The transport of the neurotransmitter glutamate from astrocytes to neurons appears to regulate astrocyte calcium [321]. Glutamate is involved in a number of physiologic processes including learning and memory and the $\mathrm{N}$-methyl-D-aspartate (NMDA) receptor has been shown to play an important role in emotional memory and fear [322]. Astrocytes can release glutamate in a calcium-dependent manner possibly under $\mathrm{A} \beta$ induction or hormonal regulation [323] [324]. However, glutamate is also involved in pathologic processes as in neurons and astrocytes glutamate toxicity can lead to cell death which can be induced by alterations in calcium levels [324] [325]. The calcium levels are regulated by GPCRs [212] [213], or via activated ion channels such as the NMDA receptors that are also under regulation by oligomeric abeta, GCPRs/protein kinase $\mathrm{C}$ or effects mediated by apolipoprotein E (apoE), oxytocin and leptin [326]-[333].

\section{Nutrition Based Strategies to Prevent Insulin Resistance, Cardiovascular Disease, Stroke and Alzheimer's Disease}

Many studies have confirmed the link between high fat/high sugar (HFS) diets and declining cognitive function and suggest a role for insulin resistance and diet-induced endocrine abnormalities in this process [6] [8] [38] [334]-[338]. Diets that contain high saturated fat, cholesterol, added sugar, including high fructose corn syrup (HFCS), and high glycemic containing foods contribute to dyslipidemia [338], ceramide and cholesterol dysregulation associated with APP-abeta processing abnormalities. In contrast to the standard Western diet, containing high fat, high refined sugar, low fibre and high salt, the Mediterranean diet low with all these contents [7] [8] has been shown to reduce the risk for AD. These diets are associated with high intakes of vegetables, legumes, fruits, cereals and unsaturated fatty acids (mainly as oleic acid 18:1n-9, the monounsaturated fatty acid found in olive oil). The focus is on high fibre, non-refined carbohydrates, making this a low glycemic eating plan which helps prevent insulin resistance and NAFLD.

High fish consumption is inversely correlated with the development of dementia and moderate alcohol consumption appears to offer a protective effect [6] [339] [340]. Fish contains high levels of omega-3 fatty acids, docosahexaenoic acid (DHA 22:6n-3) and eicosapentaenoic acid (EPA 20:5n-3). The brain relies on a supply of 


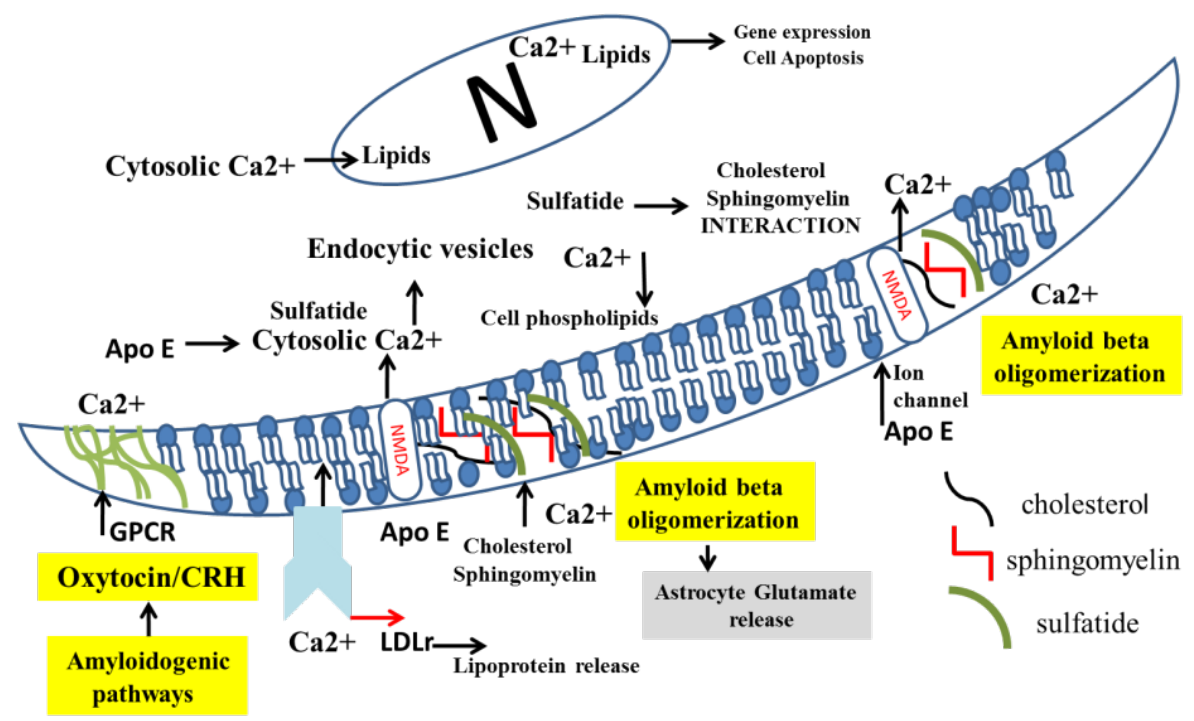

Figure 7. The role of calcium and lipids on neuron proliferation with affects on cell and nuclear membranes that control cell function and metabolism.

arachidonic acid (AA) and DHA from the periphery, which are delivered via plasma lipoproteins and lysophopholipids. The PUFAs are converted via the action of cycloxygenase and lipoxygenase enzymes to prostaglandins, leukotrienes, thromboxanes and other metabolites which are important mediators of cellular function and therefore the signaling molecules generated are partly influenced by dietary intakes [341]. High intakes of omega- 6 fatty acids and AA from processed food can elevate pro-inflammatory eicosanoids and up-regulate pro-inflammatory cytokines. Levels of the non-enzymatically derived isoprostanes, which are vasoconstrictive, are also elevated in AA enriched diets [342].

Conversely, diets enriched with DHA from fish and fish oil are more anti-inflammatory, anti-thrombotic and vasodilatory and have neuroprotective effects in terms of synaptic function and plasticity via generation of docosanoids [342] [343]. The ratio of dietary AA to DHA may also contribute to the increased risk of developing several diseases, including cardiovascular disease and $\mathrm{AD}$ and relative amounts may be an important consideration in the design of nutrition-based strategies for disease prevention [344]. DHA and EPA are important in reducing triglyceride levels as they regulate the activity of various nuclear receptors resulting in a repartitioning of fatty acids away from storage as triglycerides and towards oxidation and reducing the amount of free fatty acids available for VLDL synthesis. EPA and DHA are highly unsaturated and are prone to peroxidation which stimulates the degradation of apolipoprotein B (apoB), required for VLDL synthesis and their presence in lipoproteins may also enhance postprandial chylomicron clearance by stimulating lipoprotein lipase activity [345]. The carbohydrate responsive element binding protein (ChREBP) is a transcription factor that responds to glucose levels and is involved in hepatic lipid synthesis by the transcription of genes involved in lipogenesis, such as fatty acid synthase and acetylCoA carboxylase [346]. ChREBP activity can be inhibited or normalized by omega-3 fatty acids [346].

Dietary calcium intakes in individuals with neuroendocrine disease and chronic disease may also bean important factor to consider when designing nutrition based strategies for the prevention of stroke, neurodegeneration and chronic disease [190] [347] [348]. The mechanistic intervention of diet to maintain cellular calcium and A $\beta$ homeostasis possibly involves cell membranes, receptors and calcium regulating hormones. Interests in dietary calcium such as low calcium intake have been associated with stroke and chronic disease in Asian populations [349]. However in United States and European populations low calcium intake as a mechanism was inadequate to explain the risk for stroke [350]. The use of calcium supplements and calcium fortified foods with low fat content from dairy food may assist in the poor dietary choices that lead to low calcium intake in various populations. Excessive intake of calcium with calcium supplements should be monitored to prevent stroke and myocardial infarction [350] [351].

Flavonoids and their effects on astrocyte-neuron interactions [352]-[355] are being studied in relation to the 
consumption of diets that include fruits, vegetables and beverages rich in phytosterols and short chain fatty acids [356]. Flavonoids are also found in high fibre diets and are polyphenolic compounds such as flavonols, flavones, flavanones, isoflavones, catechins, anthocyanidins and chalcones. Flavonoids are considered to be anti-amyloidogenic and are being investigated as potential therapeutic agents to prevent the formation of $\mathrm{A} \beta$ fibrils [357][360] and also for reversal of NAFLD [361] [362]. Furthermore flavonoid intake may also prevent and reduce the risk of stroke, AD and PD [363]-[365]. Flavonoids have also been shown to affect calcium homeostasis via modulation of Ca pump function [366]. However high flavonoid intake has been suggested to interfere with many aspects of thyroid hormone synthesis and availability [367]-[370], however these effects may be influenced by the type of flavonoid and natural food sources. Commercial sources of flavonoid (e.g. quercetin) present in commercial wines [371] may be more readily oxidized than the flavonoids found in natural foods (myricetin, kaempferol, luteolin, and apigenin, hesperidin, rutin, glycosides and tangeritin) which may explain the association between flavonoids and thyroid disease with effects on stroke and AD [372]-[376]. Diets rich in fibre are suggested to be important in the treatment of NAFLD. Additionally diets rich in selenium, iodine, zinc, iron, copper, omega 3 fats, coconut oil and antioxidant vitamins A, B, C, Ecan help neutralize oxidative stress and inflammation in the periphery and also support thyroid gland function. In the CNS these dietsmay promote astrocyte-neuron interactions by maintaining of thyroid hormone synthesis and brain oxytocin release which also influences brain calcium homeostasis. High fibre diets minimize rapid changes in blood glucose and therefore stabilise insulin, leptin, and triacylglycerol levels in addition to effects on satiety [356]. Furthermore, reduced total calorie intakes [356] with adequate protein intake activate specific astrocyte and neuron nuclear receptors that act as metabolic sensors for the calorie sensitive Sirt 1 gene involved in DNA repair [165] [189] [377]-[379]. Sirt1 acts with other transcription factors such as PGC-1alpha and adenosine monophosphate-kinase (AMPK)to regulate energy intakes which may help prevent development of metabolic syndrome, NAFLD [45] [165] [189] and other associated diseases such as stroke [380] [381], cardiovascular diseaseand neurodegenerative disease. Apart from dietary considerations data from observational studies indicate that several lifestyle factors can reduce the risk of developing insulin resistance and $\mathrm{AD}$, including physical activity, mental stimulation, being a non-smoker, and social interaction. Being physically active has known beneficial effects on insulin sensitivity, lipid profiles and NAFLD with intensity of physical activity positively associated with improved insulin resistance and cognition [382] and $\mathrm{A} \beta$ metabolism.

\section{Conclusion}

The global epidemic of obesity and metabolic dysfunction and its related diseases such as diabetes, cardiovascular disease, hypertension, stroke and neurodegeneration is a major concern in Western countries. Consideration of nutrigenomic factors may increase the effectiveness of dietary programs designed to reduce the incidence of these conditions. The combination of increased oxidative stress and dyslipidemia adversely affects calciummembrane lipid interactions which are accompanied by marked changes in transcription factors and gene expression in the liver and brain. The nature of dietary lipids and calcium intake in man may determine the severity and progression rate of chronic diseases. In developed countries high glycemic load and high fat diets induce ceramide dysregulation with insulin resistance which has been shown to affect astrocyte and neuron function with particular effects on calcium and lipid homeostasis, which in those individuals with neuroendocrine abnormalities can increase susceptibility to cerebrovascular disease and AD. Abnormal lipid and calcium metabolism as observed in hypothyroidism, obesity and diabetes lead to connected to premature brain aging with the poor maintenance of astrocyte survival and additionally abnormal $\mathrm{A} \beta$ metabolism. Specific diets, by their cellular nutrigenomic effects may improve astrocyte-neuron dysfunction in these chronic diseases. Calorie restricted diets that contain adequate protein and important unsaturated fatty acids activate nuclear receptors that may help prevent astrocyte dysfunction, thereby reducing the severity of neurodegeneration and lessening the impact of the $\mathrm{AD}$ and stroke epidemics in developed and developing countries.

\section{References}

[1] Blennow, K., de Leon, M.J. and Zetterberg, H. (2006) Alzheimer’s Disease. The Lancet, 368, 387-403. http://dx.doi.org/10.1016/S0140-6736(06) 69113-7

[2] Roses, A., Alberts, M. and Strittmatter, W. (1992) Alzheimer's Disease-Reassessing the Data. Current Biology, 2, 7-9. http://dx.doi.org/10.1016/0960-9822(92) 90400-5 
[3] Brookmeyer, R., Johnson, E., Ziegler-Graham, K. and Arrighi, H.M. (2007) Forecasting the Global Burden of Alzheimer's Disease. Alzheimer's Dementia: The Journal of the Alzheimer's Association, 3, 186-191. http://dx.doi.org/10.1016/j.jalz.2007.04.381

[4] Ferri, C.P., Prince, M., Brayne, C., Brodaty, H., Fratiglioni, L., Ganguli, M., et al. (2005) Global Prevalence of Dementia: A Delphi Consensus Study. The Lancet, 366, 2112-2117. http://dx.doi.org/10.1016/S0140-6736(05) 67889-0

[5] Access, Delaying Onset of Alzheimer's Disease: Predictions and Issues (Internet). 2004-2009 Report No. 30.

[6] Luchsinger, J.A. and Mayeux, R. (2004) Dietary Factors and Alzheimer's Disease. The Lancet Neurology, 3, 579-587. http://dx.doi.org/10.1016/S1474-4422(04) 00878-6

[7] Scarmeas, N., Stern, Y., Tang, M.X., Mayeux, R. and Luchsinger, J.A. (2006) Mediterranean Diet and Risk for Alzheimer's Disease. Annals of Neurology, 59, 912-921. http://dx.doi.org/10.1002/ana.20854

[8] Gu, Y., Nieves, J.W., Stern, Y., Luchsinger, J.A. and Scarmeas, N. (2010) Food Combination and Alzheimer Disease Risk: A Protective Diet. Archives of Neurology, 67, 699-706. http://dx.doi.org/10.1001/archneurol.2010.84

[9] Dietschy, J.M. (1998) Dietary Fatty Acids and the Regulation of Plasma Low Density Lipoprotein Cholesterol Concentrations. Journal of Nutrition, 128, 444S-448S.

[10] Woollett, L.A., Spady, D.K. and Dietschy, J.M. (1992) Regulatory Effects of the Saturated Fatty Acids 6:0 through 18:0 on Hepatic Low Density Lipoprotein Receptor Activity in the Hamster.TheJournal of Clinical Investigation, 89, 1133-1141. http://dx.doi.org/10.1172/JCI115694

[11] Woollett, L.A., Spady, D.K. and Dietschy, J.M. (1992) Saturated and Unsaturated Fatty Acids Independently Regulate Low Density Lipoprotein Receptor Activity and Production Rate. Journal of Lipid Research, 33, 77-88.

[12] Prudovsky, I., Vary, C.P.H., Markaki, Y., Olins, A.L. and Olins, D.E. (2012) Phosphatidylserine Colocalizes with Epichromatin in Interphase Nuclei and Mitotic Chromosomes. Nucleus, 3, 200-210. http://dx.doi.org/10.4161/nucl.19662

[13] Tata, J.R., Hamilton, M.J. and Cole, D.R. (1972) Membrane Phospholipids Associated with Nuclei and Chromatin: Melting Profile, Template Activity and Stability of Chromatin. Journal of Molecular Biology, 67, 231-236. http://dx.doi.org/10.1016/0022-2836(72) 90238-0

[14] Viiri, K., Mäki, M. and Lohi, O. (2012) Phosphoinositides as Regulators of Protein-Chromatin Interactions. Science Signaling, 5, pe19. http://dx.doi.org/10.1126/scisignal.2002917

[15] Jones, D.R. and Divecha, N. (2004) Linking Lipids to Chromatin. Current Opinion Genetic Development, 14, $196-202$. http://dx.doi.org/10.1016/j.gde.2004.02.003

[16] Laclette, J.P. and Montal, M. (1977) Interaction of Calcium with Negative Lipids in Planar Bilayer Membranes. Influence of the Solvent. Biophysical Journal, 19, 199-202. http://dx.doi.org/10.1016/S0006-3495(77) 85581-1

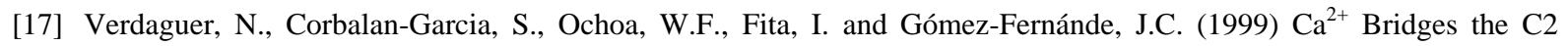
Membrane-Binding Domain of Protein Kinase C $\alpha$ Directly to Phosphatidylserine. The EMBO Journal, 18, 6329-6338. http://dx.doi.org/10.1093/emboj/18.22.6329

[18] Bazan, N.G. (2005) Lipid Sigaling in Neural Plasticity, Brain Repair, and Neuroprotection. Molecular Neurobiology, 32, 89-103. http://dx.doi.org/10.1385/MN:32:1:089

[19] Wymann, M.P. and Schneiter, R. (2008) Lipid Signalling in Disease. Nature Review Molecular Cellular Biology, 9, 162-176. http://dx.doi.org/10.1038/nrm2335

[20] Fernandis, A.Z. and Wenk, M.R. (2007) Membrane Lipids as Signaling Molecules. Current Opinion Lipidology, 18, 121-128. http://dx.doi.org/10.1097/MOL.0b013e328082e4d5

[21] Verdile, G., Fuller, S., Atwood, C.S., Laws, S.M., Gandy, S.E. and Martins, R.N. (2004) The Role of Beta Amyloid in Alzheimer's Disease: Still a Cause of Everything or the Only One Who Got Caught? Pharmacology Research, 50, 397-409. http://dx.doi.org/10.1016/j.phrs.2003.12.028

[22] Attems, J., Quass, M., Jellinger, K.A. and Lintner, F. (2007) Topographical Distribution of Cerebral Amyloid Angiopathy and Its Effect on Cognitive Decline Are Influenced by Alzheimer Disease Pathology. Journal of the Neurological Science, 257, 49-55. http://dx.doi.org/10.1016/j.jns.2007.01.013

[23] Di Paolo, G. and Kim, T.W. (2011) Linking Lipids to Alzheimer's Disease: Cholesterol and Beyond. Nature Reveiw Neuroscience, 12, 284-296. http://dx.doi.org/10.1038/nrn3012

[24] Martins, I.J., Berger, T., Sharman, M.J., Verdile, G., Fuller, S.J. and Martins. R/N. (2009) Cholesterol Metabolism and Transport in the Pathogenesis of Alzheimer's Disease. Journal of Neurochemistry, 111, 1275-1308. http://dx.doi.org/10.1111/j.1471-4159.2009.06408.x

[25] Martins, I.J., Hone, E., Foster, J.K., Sünram-Lea, S.I., Gnjec, A., Fuller, S.J., et al. (2006) Apolipoprotein E, Cholesterol Metabolism, Diabetes and the Convergence of Risk Factors for Alzheimer's Disease and Cardiovascular Disease. 
Molecular Psychiatry, 11, 721-736. http://dx.doi.org/10.1038/sj.mp.4001854

[26] Piomelli, D., Astarita, G. and Rapaka, R. (2007) A Neuroscientist’s Guide to Lipidomics. Nature Reveiw Neuroscience, 8, 743-754. http://dx.doi.org/10.1038/nrn2233

[27] Roher, A.E., Kuo, Y.M., Kokjohn, K.M., Emmerling, M.R. and Gracon, S. (1999) Amyloid and Lipids in the Pathology of Alzheimer's Disease. Amyloid, 6, 136-145. http://dx.doi.org/10.3109/13506129909007315

[28] Kuo, Y.M., Emmerlingb, M.R., Bisgaierc, C.L., Essenburgc, A.D., Lamperta, H.C., Drumm, D., et al. (1998) Elevated Low Density Lipoprotein in Alzheimer's Disease Correlates with Brain Abeta 1-42 Levels. Biochimica Biophysica Research Communications, 252, 711-715. http://dx.doi.org/10.1006/bbrc.1998.9652

[29] Merched, A., Xia, Y., Visvikis, S., Serot, J.M. and Siest, G. (2000) Decreased High-Density Lipoprotein Cholesterol and Serum Apolipoprotein AI Concentrations Are Highly Correlated with the Severity of Alzheimer's Disease. Neurobiology Ageing, 21, 27-30. http://dx.doi.org/10.1016/S0197-4580(99) 00103-7

[30] Selkoe, D.J. (2004) Cell Biology of Protein Misfolding: The Examples of Alzheimer's and Parkinson’s Diseases. Nature Cell Biology, 6, 1054-1061. http://dx.doi.org/10.1038/ncb1104-1054

[31] Wenk, M.R. (2005) The Emerging Field of Lipidomics. Nature Reveiw Drug Discovery, 4, 594-610. http://dx.doi.org/10.1038/nrd1776

[32] Craft, S. (2009) The Role of Metabolic Disorders in Alzheimer Disease and Vascular Dementia: Two Roads Converged. Archives of Neurology, 66, 300-305. http://dx.doi.org/10.1001/archneurol.2009.27

[33] Farooqui, A.A., Farooqui, T., Panza, F. and Frisardi, V. (2012) Metabolic Syndrome as a Risk Factor for Neurological Disorders. Cell and Molecular Life Science, 69, 741-762. http://dx.doi.org/10.1007/s00018-011-0840-1

[34] Frisardi, V. and Imbimbo B.P. (2012) Metabolic-Cognitive Syndrome: Metabolic Approach for the Management of Alzheimer's Disease Risk. Journal of Alzheimer's Disease, 30, S1-S4.

[35] Merlo, S., Spampinato, S., Canonico, P.L., Copani, A. and Sortino, M.A. (2010) Alzheimer’s Disease: Brain Expression of a Metabolic Disorder? Trends in Endocrinology \& Metabolism, 21, 537-544. http://dx.doi.org/10.1016/j.tem.2010.05.005

[36] Luchsinger, J.A. (2012) Type 2 Diabetes and Cognitive Impairment: Linking Mechanisms. Journal of Alzheimer's Disease, 30, S185-S198.

[37] Moreira, P.I. (2012) Alzheimer's Disease and Diabetes: An Integrative View of the Role of Mitochondria, Oxidative stress, and Insulin. Journal of Alzheimer's Disease, 30, S199-S215.

[38] Craft, S. (2005) Insulin Resistance Syndrome and Alzheimer's Disease: Age- and Obesity-Related Effects on Memory, Amyloid, and Inflammation. Neurobiology of Ageing, 26, 65-69. http://dx.doi.org/10.1016/j.neurobiolaging.2005.08.021

[39] Watson, G.S. and Craft, S. (2003) The Role of Insulin Resistance in the Pathogenesis of Alzheimer's Disease: Implications for Treatment. Central Nervous System Drugs, 17, 27-45.

[40] De Felice, F.G., Lourenco, M.V. and Ferreira, S.T. (2014) How Does Brain Insulin Resistance Develops in Alzheimer's Disease? Alzheimers Dementia, 10, S26-S32.

[41] Chiu, S.L., Chen, C.M. and Cline, H.T. (2008) Insulin Receptor Signaling Regulates Synapse Number, Dendritic Plasticity, and Circuit Function in Vivo. Neuron, 58, 708-719. http://dx.doi.org/10.1016/j.neuron.2008.04.014

[42] Shoelson, S.E., Lee, J. and Goldfine, A.B. (2006) Inflammation and Insulin Resistance. Journal Clinical Investigation, 116, 1793-1801. http://dx.doi.org/10.1172/JCI29069

[43] Rizos, C.V., Elisaf, M.S. and Liberopoulos, E.N. (2001) Effects of Thyroid Dysfunction on Lipid Profile. The Open Cardiovascular Medical Journal, 5, 76-84. http://dx.doi.org/10.2174/1874192401105010076

[44] Quinlan, P., Nordlund, A., Lind, K., Gustafson, D., Edman, Å. and Wallin A. (2010) Thyroid Hormones Are Associated with Poorer Cognition in Mild Cognitive Impairment. Dementia Geriatric Cognition Disorder, 30, 205-211. http://dx.doi.org/10.1159/000319746

[45] Martins, I.J., Creegan, R., Lim, W.L.F. and Martins, R.N. (2013) Molecular Insights into Appetite Control and Neuroendocrine Disease as Risk Factors for Chronic Diseases in Western Countries. Open Journal of Endocrine and Metabolic Diseases, 3, 11-33. http://dx.doi.org/10.4236/ojemd.2013.35A002

[46] Burgess, B.L., McIsaac, S.A, Naus, K.E., Chan, J.Y., Tangsley, G.H., Yang, J., et al. (2006) Elevated plasma triglyceride levels precede amyloid deposition in Alzheimer's disease mouse models with abundant A beta in plasma. Neurobiology of Disease, 24, 114-127.

[47] Chavez, J.A. and Summers, S.A. (2012) A Ceramide-Centric View of Insulin Resistance. Cell Metabolism, 15, 585594. http://dx.doi.org/10.1016/j.cmet.2012.04.002

[48] Summers, S.A. (2006) Ceramides in Insulin Resistance and Lipotoxicity. Progress in Lipid Research, 45, 42-72. 
http://dx.doi.org/10.1016/j.plipres.2005.11.002

[49] Kowalski, G.M., Carey, A.L., Selathurai, A., Kingwell, B.A. and Bruce, C.R. (2013) Plasma Sphingosine-1-Phosphate Is Elevated in Obesity. PLoS ONE, 8, e72449. http://dx.doi.org/10.1371/journal.pone.0072449

[50] Hammad, S.M., Al Gadban, M.M., Semler, A.J. and Klein, R.L. (2012) Sphingosine 1-Phosphate Distribution in Human Plasma: Associations with Lipid Profiles. Journal of Lipids, 2012, Article ID: 180705. http://dx.doi.org/10.1155/2012/180705

[51] Samad, F., Hester, K.D., Yang, G., Hannun, Y.A. and Bielawski, J. (2006) Altered Adipose and Plasma Sphingolipid Metabolism in Obesity: A Potential Mechanism for Cardiovascular and Metabolic Risk. Diabetes, 55, 2579-2587. http://dx.doi.org/10.2337/db06-0330

[52] Blachnio-Zabielska, A.U., Koutsari, C., Tchkonia, T. and Jensen, M.D. (2012) Sphingolipid Content of Human Adipose Tissue: Relationship to Adiponectin and Insulin Resistance. Obesity (Silver Spring) , 20, 2341-2347. http://dx.doi.org/10.1038/oby.2012.126

[53] Bikman, B.T. (2012) A Role for Sphingolipids in the Pathophysiology of Obesity-Induced Inflammation. Cellular and Molecular Life Sciences, 69, 2135-2146. http://dx.doi.org/10.1007/s00018-012-0917-5

[54] Kang, S.C., Kim, B.R., Lee, S.Y. and Park, T.S. (2013) Sphingolipid Metabolism and Obesity-Induced Inflammation. Frontiers in Endocrinology (Lausanne) , 4, 67.

[55] Wilkerson, B.A., Grass, G.D., Wing, S.B., Argraves, W.S. and Argraves, K.M. (2012) Sphingosine 1-Phosphate (S1P) Carrier-Dependent Regulation of Endothelial Barrier: High Density Lipoprotein (HDL) -S1P Prolongs Endothelial Barrier Enhancement as Compared with Albumin-S1P via Effects on Levels, Trafficking, and Signaling of S1P1. TheJournal of Biological Chemistry, 287, 44645-44653. http://dx.doi.org/10.1074/jbc.M112.423426

[56] Murata, N., Sato, K., Kon, J., Tomura, H., Yanagita, M., Kuwabara, A., et al. (2000) Interaction of Sphingosine 1-Phosphate with Plasma Components, Including Lipoproteins, Regulates the Lipid Receptor-Mediated Actions. Biochemical Journal, 352, 809-815. http://dx.doi.org/10.1042/0264-6021:3520809

[57] Sattler, K. and Levkau, B. (2009) Sphingosine-1-Phosphate as a Mediator of High-Density Lipoprotein Effects in Cardiovascular Protection. Cardiovascular Research, 82, 201-211. http://dx.doi.org/10.1093/cvr/cvp070

[58] Dahm, F., Nocito, A., Bielawska, A., Lang, K.S., Georgiev, P., Asmis, L.M., et al. (2006) Distribution and Dynamic Changes of Sphingolipids in Blood in Response to Platelet Activation. Journal of Thrombosis and Haemostasis, 4, 2704-2709. http://dx.doi.org/10.1111/j.1538-7836.2006.02241.x

[59] Tao, R.V., Sweeley, C.C. and Jamieson, G.A. (1973) Sphingolipid Composition of Human Platelets. Journal of Lipid Research, 14, 16-25.

[60] Saniabadi, A.R., Umemura, K., Shimoyama, M., Adachi, M., Nakano, M. and Nakashima, M. (1997) Aggregation of Human Blood Platelets by Remnant Like Lipoprotein Particles of Plasma Chylomicrons and Very Low Density Lipoproteins. Thrombosis Haemostasis, 77, 996-1001.

[61] Relou, I.A., Hackeng, C.M., Akkerman, J.W. and Malle, E. (2003) Low-Density Lipoprotein and Its Effect on Human Blood Platelets. Cell Molecular\& Life Science, 60, 961-971.

[62] Anfossi, G., Russo, I. and Trovati, M. (2009) Platelet Dysfunction in Central Obesity. Nutrition, Metabolism \& Cardiovascular Disease, 19, 440-449. http://dx.doi.org/10.1016/j.numecd.2009.01.006

[63] Santilli, F., Vazzana, N., Liani, R., Guagnano, M.T. and Davì, G. (2011) Platelet Activation in Obesity and Metabolic Syndrome. Obesity Reviews, 13, 27-42. http://dx.doi.org/10.1111/j.1467-789X.2011.00930.x

[64] Casoli, T., Di Stefano, G., Giorgetti, B., Grossi, Y., Balietti, M., Fattoretti, P. and Bertoni-Freddari, C. (2007) Release of Beta-Amyloid from High-Density Platelets: Implications for Alzheimer's Disease Pathology. Annuals of the New York Academy of Science, 1096, 170-178. http://dx.doi.org/10.1196/annals.1397.082

[65] Chen, M., Inestrosa, N.C., Ross, G.S. and Fernandez, H.L. (1995) Platelets Are the Primary Source of Amyloid Beta-Peptide in Human Blood. Biochemical \& Biophysic Research Communications, 213, 96-103. http://dx.doi.org/10.1006/bbrc.1995.2103

[66] Park, T.S., Hu, Y., Noh, H.L., Drosatos, K., Okajima, K., Buchanan, J., et al. (2008) Ceramide Is a Cardiotoxin in Lipotoxic Cardiomyopathy. Journal of Lipid Research, 49, 2101-2112. http://dx.doi.org/10.1194/jlr.M800147-JLR200

[67] Bikman, B.T. and Summers, S.A. (2011) Ceramides as Modulators of Cellular and Whole-Body Metabolism. Journal of Clinical Investigation, 121, 4222-4230. http://dx.doi.org/10.1172/JCI57144

[68] Ussher, J.R., Koves, T.R., Cadete, V.J., Zhang, L., Jaswal, J.S., Swyrd, S.J., et al. (2010) Inhibition of De Novo Ceramide Synthesis Reverses Diet-Induced Insulin Resistance and Enhances Whole-Body Oxygen Consumption. Diabetes, 59, 2453-2464. http://dx.doi.org/10.2337/db09-1293

[69] Galadari, S., Rahman, A., Pallichankandy, S., Galadari, A. and Thayyullathil, F. (2013) Role of Ceramide in Diabetes Mellitus: Evidence and Mechanisms. Lipids in Health Disease, 12, 98. http://dx.doi.org/10.1186/1476-511X-12-98 
[70] Schmitz-Peiffer, C. (2010) Targeting Ceramide Synthesis to Reverse Insulin Resistance. Diabetes, 59, 2351-2353. http://dx.doi.org/10.2337/db10-0912

[71] Costantini, C., Kolasani, R.M. and Puglielli, L. (2005) Ceramide and Cholesterol: Possible Connections between Normal Ageing of the Brain and Alzheimer's Disease. Just Hypotheses or Molecular Pathways to Be Identified? Alzheimer's \& Dementia: The Journal of the Alzheimer's Association, 1, 43-50. http://dx.doi.org/10.1016/j.jalz.2005.06.004

[72] Hussain, M.M., Jin, W. and Jiang, X.C. (2012) Mechanisms Involved in Cellular Ceramide Homeostasis. Nutrition \& Metabolism (London) , 9, 71. http://dx.doi.org/10.1186/1743-7075-9-71

[73] Filippov, V., Song, M.A., Zhang, K., Vinters, H.V., Tung, S., Kirsch, W.M., et al. (2012) Increased Ceramide in Brains with Alzheimer's and Other Neurodegenerative Diseases. Journal of Alzheimer's Disease, 29, 537-547.

[74] Satoi, H., Tomimoto, H., Ohtani, R., Kitano, T., Kondo, T., Watanabe, M., et al. (2005) Astroglial Expression of Ceramide in Alzheimer's Disease Brains: A Role during Neuronal Apoptosis. Neuroscience, 130, 657-666. http://dx.doi.org/10.1016/j.neuroscience.2004.08.056

[75] Mielke, M.M., Bandaru, V.V., Haughey, N.J., Xia, J., Fried, L.P., Yasar, S., et al. (2012) Serum Ceramides Increase the Risk of Alzheimer Disease: The Women's Health and Ageing Study II. Neurology, 14, 633-641. http://dx.doi.org/10.1212/WNL.0b013e318264e380

[76] Yuyama, K., Mitsutake, S. and Igarashi, Y. (2013) Pathological Roles of Ceramide and Its Metabolites in Metabolic Syndrome and Alzheimer's Disease.Biochimica et Biophysica Acta (BBA), Molecular and Cell Biology of Lipids, 1841, 793-798. http://dx.doi.org/10.1016/j.bbalip.2013.08.002

[77] Corder, E.H., Saunders, A.M., Strittmatter, W.J., Schmechel, D.E., Gaskell, P.C., Small, G.W., et al. (1993) Gene Dose of Apolipoprotein E Type 4 Allele and the Risk of Alzheimer's Disease in Late onset Families. Science, 261, 921-923. http://dx.doi.org/10.1126/science.8346443

[78] Saunders, A.M., Strittmatter, W.J., Schmechel, D., St. George-Hyslop, P.H., Pericak-Vance, M.A., Joo, S.H., et al. (1993) Association of Apolipoprotein E Allele Epsilon 4 with Late-Onset Familial and Sporadic Alzheimer's Disease. Neurology, 43, 1467-1472. http://dx.doi.org/10.1212/WNL.43.8.1467

[79] Rall, S.C., Weisgraber, K.H. and Mahley, R.W. (1982) Human Apolipoprotein E. The Complete Amino Acid Sequence. Journal of Biological Chemistry, 257, 4171-4178.

[80] Weisgraber, K.H., Innerarity, T.L. and Mahley, R.W. (1982) Abnormal Lipoprotein Receptor-Binding Activity of the Human E Apoprotein Due to Cysteine-Arginine Interchange at a Single Site. Journal of Biological Chemistry, 257, 2518-2521.

[81] Mahley, R.W. and Huang, Y. (1999) Apolipoprotein E: From Atherosclerosis to Alzheimer’s Disease and Beyond. Current Opinion in Lipidology, 10, 207-217. http://dx.doi.org/10.1097/00041433-199906000-00003

[82] Feussner, G., Feussner, V., Hoffmann, M.M., Lohrmann, J., Wieland, H. and März, W. (1998) Molecular Basis of Type III Hyperlipoproteinemia in Germany. Human Mutation, 11, 417-423.

[83] Huang, X., Chen, P.C. and Poole, C. (2004) APOE-[Epsilon]2 Allele Associated with Higher Prevalence of Sporadic Parkinson Disease. Neurology, 62, 2198-2202. http://dx.doi.org/10.1212/01.WNL.0000130159.28215.6A

[84] Strittmatter, W.J., Saunders, A.M., Schmechel, D., Pericak-Vance, M., Enghild, J., Salvesen, G.S., et al. (1993) Apolipoprotein E: High-Avidity Binding to Beta-Amyloid and Increased Frequency of Type 4 Allele in Late-Onset Familial Alzheimer Disease. Proceedings of the National Academy of Sciences of the United States of America, 90, 1977-1981. http://dx.doi.org/10.1073/pnas.90.5.1977

[85] Deary, I.J., Whiteman, M.C., Pattie, A., Starr, J.M., Hayward, C., Wright, A.F., et al. (2002) Cognitive Change and the APOE Epsilon 4 Allele. Nature, 418, 932. http://dx.doi.org/10.1038/418932a

[86] Chapman, J., Vinokurov, S., Achiron, A., Karussis, D.M., Mitosek-Szewczyk, K., Birnbaum, M., et al. (2011) APOE Genotype Is a Major Predictor of Long-Term Progression of Disability in MS. Neurology, 56, 312-316. http://dx.doi.org/10.1212/WNL.56.3.312

[87] McCarron, M.O., Delong, D. and Alberts, M.J. (1999) APOE Genotype as a Risk Factor for Ischemic Cerebrovascular Disease: A Meta-Analysis. Neurology, 53, 1308-1311. http://dx.doi.org/10.1212/WNL.53.6.1308

[88] Kadotani, H., Kadotani, T., Young, T., Peppard, P.E., Finn, L., Colrain, I.M., et al. (2001) Association between Apolipoprotein E Epsilon4 and Sleep-Disordered Breathing in Adults. Journal of American Medical Association, 285, 28882890. http://dx.doi.org/10.1001/jama.285.22.2888

[89] Gottlieb, D.J., DeStefano, A.L., Foley, D.J., Mignot, E., Redline, S., Givelber, R.J., et al. (2004) APOE Epsilon4 Is Associated with Obstructive Sleep Apnea/Hypopnea: The Sleep Heart Health Study. Neurology, 63, 664-668. http://dx.doi.org/10.1212/01.WNL.0000134671.99649.32

[90] Martins, R.N., Clarnette, R., Fisher, C., Broe, G.A., Brooks, W.S., Montgomery, P., et al. (1995) ApoE Genotypes in Australia: Roles in Early and Late Onset Alzheimer's Disease and Down's Syndrome. Neuroreport, 6, 1513-1516. 
http://dx.doi.org/10.1097/00001756-199507310-00012

[91] Bales, K.R., Dodart, J.C., DeMattos, R.B., Holtzman, D.M. and Paul, S.M. (2002) Apolipoprotein E, Amyloid, and Alzheimer Disease. Molecular Interventions, 2, 363-375. http://dx.doi.org/10.1124/mi.2.6.363

[92] Zheng, H. and Koo, E.H. (2006) The Amyloid Precursor Protein: Beyond Amyloid. Molecular Neurodegeneration, 1, 5. http://dx.doi.org/10.1186/1750-1326-1-5

[93] Beel, A.J., Sakakura, M., Barrett, P.J. and Sanders, C.R. (2010) Direct Binding of Cholesterol to the Amyloid Precursor Protein: An Important Interaction in Lipid-Alzheimer's Disease Relationships? Biochimica et Biophysica Acta (BBA) , Molecular and Cell Biology of Lipids, 1801, 975-982. http://dx.doi.org/10.1016/j.bbalip.2010.03.008

[94] Korade, Z. and Kenworthy, A.K. (2008) Lipid Rafts, Cholesterol, and the Brain. Neuropharmacology, 55, 1265-1273. http://dx.doi.org/10.1016/j.neuropharm.2008.02.019

[95] Zhang, Y.W. and Xu, H. (2007) Molecular and Cellular Mechanisms for Alzheimer’s Disease: Understanding APP Metabolism. Current Molecular Medicine, 7, 687-696.

[96] O’Brien, R.J. and Wong P.C. (2011) Amyloid Precursor Protein Processing and Alzheimer’s Disease. Annual Reveiw Neuroscience, 34, 185-204.

[97] Zhang, Y.W., Thompson, R., Zhang, H. and Xu, H. (2011) APP Processing in Alzheimer’s Disease. Molecular Brain, 4, 1-13.

[98] Zhang, Q., Yang, G., Li, W., Fan, Z., Sun, A., Luo, J. and Ke, Z.J. (2011) Thiamine Deficiency Increases Beta-Secretase Activity and Accumulation of Beta-Amyloid Peptides. Neurobiology of Ageing, 32, 42-53. http://dx.doi.org/10.1016/j.neurobiolaging.2009.01.005

[99] Puglielli, L., Ellis, B.C., Saunders, A.J. and Kovacs, D.M. (2002) Ceramide Stabilizes Beta-Site Amyloid Precursor Protein-Cleaving Enzyme 1 and Promotes Amyloid Beta-Peptide Biogenesis. Journal of Biological Chemistry, 278, 19777-19783. http://dx.doi.org/10.1074/jbc.M300466200

[100] Li, H., Kim, W.S., Guillemin, G.J., Hill, A.F., Evin, G. and Garner, B. (2010) Modulation of Amyloid Precursor Protein Processing by Synthetic Ceramide Analogues. Biochimca et Biophysica Acta (BBA), Molecular and Cell Biology of Lipids, 1801, 887-895

[101] Takasugi, N., Sasaki, T., Suzuki, K., Osawa, S., Isshiki, H., Hori, Y., et al. (2011) BACE1 Activity Is Modulated by Cell-Associated Sphingosine-1-Phosphate. The Journal of Neuroscience, 31, 6850-6857. http://dx.doi.org/10.1523/JNEUROSCI.6467-10.2011

[102] Gassowska, M., Cieslik, M., Wilkaniec, A. and Strosznajder, J.B. (2014) Sphingosine Kinases/Sphingosine-1-Phosphate and Death Signalling in APP-Transfected Cells. Neurochemical Research, 39, 645-652. http://dx.doi.org/10.1007/s11064-014-1240-3

[103] Maysinger, D., Holmes, M., Han, X., Epand, R.M., Pertens, E., Foerster, A., et al. (2008) Ceramide Is Responsible for the Failure of Compensatory Nerve Sprouting in Apolipoprotein E Knock-Out Mice. Journal of Neuroscience, 28, 7891-7899. http://dx.doi.org/10.1523/JNEUROSCI.1461-08.2008

[104] Jeong, T.S., Schissel, S.L. Tabas, I., Pownall, H.J., Tall, A.R. and Jiang, X. (1998) Increased Sphingomyelin Content of Plasma Lipoproteins in Apolipoprotein E Knockout Mice Reflects Combined Production and Catabolic Defects and Enhances Reactivity with Mammalian Sphingomyelinase. Journal of Clinical Investigation, 101, 905-912. http://dx.doi.org/10.1172/JCI870

[105] Bandaru, V.V., Troncoso, J., Wheeler, D., Pletnikova, O., Wang, J., Conant, K., et al. (2004) ApoE4 Disrupts Sterol and Sphingolipid Metabolism in Alzheimer's but Not Normal Brain. Neurobiology of Ageing, 30, 591-599. http://dx.doi.org/10.1016/j.neurobiolaging.2007.07.024

[106] Reitz, C., Tang, M.X., Luchsinger, J. and Mayeux, R.(2004) Relation of Plasma Lipids to Alzheimer Disease and Vascular Dementia. Archives of Neurology, 61, 705-714. http://dx.doi.org/10.1001/archneur.61.5.705

[107] Hayden, K.M., Zandi, P.P., Lyketsos, C.G., Khachaturian, A.S., Bastian, L.A., Charoonruk, G., et al. (2006) Vascular Risk Factors for Incident Alzheimer Disease and Vascular Dementia: The Cache County Study. Alzheimer Disease \& Association Disorders, 20, 93-100. http://dx.doi.org/10.1097/01.wad.0000213814.43047.86

[108] Reitz, C., Tang, M.X., Schupf, N., Manly, J.J., Mayeux, R. and Luchsinger, J.A. (2010) Association of Higher Levels of High-Density Lipoprotein Cholesterol in Elderly Individuals and Lower Risk of Late-Onset Alzheimer Disease. Archives of Neurology, 67, 1491-1497. http://dx.doi.org/10.1001/archneurol.2010.297

[109] Bowman, G.L., Kaye, J.A. and Quinn, J.F. (2012) Dyslipidemia and Blood-Brain Barrier Integrity in Alzheimer’s Disease. Current Gerontology and Geriatric Research, 2012, 1-5. http://dx.doi.org/10.1155/2012/184042

[110] Jiang, X.C., Bruce, C., Mar, J., Lin, M., Ji, Y., Francone, O.L., et al. (1999) Targeted Mutation of Plasma Phospholipid Transfer Protein Gene Markedly Reduces High-Density Lipoprotein Levels. Journal Clinical Investigation, 103, 907914. http://dx.doi.org/10.1172/JCI5578 
[111] Qin, S., Kawano, K., Bruce, C., Lin, M., Bisgaier, C., Tall, A.R., et al. (2000) Phospholipid Transfer Protein Gene Knock-Out Mice Have Low High Density Lipoprotein Levels, Due to Hypercatabolism, and Accumulate apoA-IVRich Lamellar Lipoproteins. Journal of Lipid Research, 41, 269-276.

[112] Jiang, X.C., Jin, W. and Hussain, M.M. (2012) The Impact of Phospholipid Transfer Protein (PLTP) on Lipoprotein Metabolism. Nutrition\& Metabolism (London) , 9, 75. http://dx.doi.org/10.1186/1743-7075-9-75

[113] Levels, J.H., Marquart, J.A., Abraham, P.R., van den Ende, A.E., Molhuizen, H.O., van Deventer, S.J., et al. (2005) Lipopolysaccharide Is Transferred from High-Density to Low-Density Lipoproteins by Lipopolysaccharide-Binding Protein and Phospholipid Transfer Protein. Infection and Immunity, 73, 2321-2326. http://dx.doi.org/10.1128/IAI.73.4.2321-2326.2005

[114] Rao, R., Albers, J.J., Wolfbauer, G. and Pownall, H.J. (1997) Molecular and Macromolecular Specificity of Human Plasma Phospholipid Transfer Protein. Biochemistry, 36, 3645-3653. http://dx.doi.org/10.1021/bi962776b

[115] Wang, H., Yu, Y., Chen, W., Cui, Y., Luo, T., Ma, J., et al. (2014) PLTP Deficiency Impairs Learning and Memory Capabilities Partially Due to Alteration of Amyloid- $\beta$ Metabolism in Old Mice. Journal of Alzheimer's Disease, 39, 79-88

[116] Desrumaux, C., Pisoni, A., Meunier, J., Deckert, V., Athias, A., Perrier, V., et al. (2013) Increased Amyloid- $\beta$ Peptide-Induced Memory Deficits in Phospholipid Transfer Protein (PLTP) Gene Knockout Mice. Neuropsychopharmacology, 38, 817-825. http://dx.doi.org/10.1038/npp.2012.247

[117] Desrumaux, C., Risold, P.Y., Schroeder, H., Deckert, V., Masson, D., Athias, A., et al. (2005) Phospholipid Transfer Protein (PLTP) Deficiency Reduces Brain Vitamin E Content and Increases Anxiety in Mice. FASEB Journal, 19, 296297.

[118] Yang, C.Y., Raya, J.L., Chen, H.H., Chen, C.H., Abe, Y., Pownall, H.J., et al. (2003) Isolation, Characterization, and Functional Assessment of Oxidatively Modified Subfractions of Circulating Low-Density Lipoproteins. Arteriosclerosis, Thrombosis, and Vascular Biology, 23, 1083-1090. http://dx.doi.org/10.1161/01.ATV.0000071350.78872.C4

[119] Huuskonen, J. and Ehnholm, C. (2000) Phospholipid Transfer Protein in Lipid Metabolism. Current Opinion in Lipidology, 11, 285-289. http://dx.doi.org/10.1097/00041433-200006000-00009

[120] Huuskonen, J., Olkkonen, V.M., Ehnholm, C., Metso, J., Julkunen, I. and Jauhiainen, M. (2000) Phospholipid Transfer Is a Prerequisite for PLTP-Mediated HDL Conversion. Biochemistry, 39, 16092-16098. http://dx.doi.org/10.1021/bi0019287

[121] Demeester, N., Castro, G., Desrumaux, C., De Geitere, C., Fruchart, J.C., Santens, P., et al. (2000) Characterization and Functional Studies of Lipoproteins, Lipid Transfer Proteins, and Lecithin: Cholesterol Acyltransferase in CSF of Normal Individuals and Patients with Alzheimer's Disease. Journal Lipid Research, 41, 963-974.

[122] Dullaart, R.P., van Tol, A. and Dallinga-Thie, G.M. (2013) Phospholipid Transfer Protein, an Emerging Cardiometabolic Risk Marker: Is It Time to Intervene? Atherosclerosis, 228, 38-41. http://dx.doi.org/10.1016/j.atherosclerosis.2013.01.043

[123] Robins, S.J., Lyass, A., Brocia, R.W., Massaro, J.M. and Vasan, R.S. (2013) Plasma Lipid Transfer Proteins and Cardiovascular Disease. The Framingham Heart Study. Atherosclerosis, 228, 230-236. http://dx.doi.org/10.1016/j.atherosclerosis.2013.01.046

[124] Schlitt, A., Bickel, C., Thumma, P., Blankenberg, S., Rupprecht, H.J., Meyer, J., et al. (2003) High Plasma Phospholipid Transfer Protein Levels as a Risk Factor for Coronary Artery Disease. Arteriosclerosis Thrombosis, Thrombosis, and Vascular Biology, 23, 1857-1862. http://dx.doi.org/10.1161/01.ATV.0000094433.98445.7F

[125] Yatsuya, H., Tamakoshi, K., Hattori, H., Otsuka, R., Wada, K., Zhang, H., et al. (2004) Serum Phospholipid Transfer Protein Mass as a Possible Protective Factor for Coronary Heart Diseases. Circulation Journal, 68, 11-16. http://dx.doi.org/10.1253/circj.68.11

[126] Schgoer, W., Mueller, T., Jauhiainen, M., Wehinger, A., Gander, R., Tancevski, I., et al. (2008) Low Phospholipid Transfer Protein (PLTP) Is a Risk Factor for Peripheral Atherosclerosis. Atherosclerosis, 196, 219-226. http://dx.doi.org/10.1016/j.atherosclerosis.2007.04.046

[127] van Tol, A. (2002) Phospholipid Transfer Protein. Current Opinion in Lipidology, 13, 135-139. http://dx.doi.org/10.1097/00041433-200204000-00004

[128] Tall, A.R., Abreu, E. and Shuman, J. (1983) Separation of a Plasma Phospholipid Transfer Protein from Cholesterol Ester/Phospholipid Exchange Protein. Journal of Biological Chemistry, 258, 2174-2180.

[129] Lightle, S., Tosheva, R., Leea, A., Queen-Bakera, J., Boyanovsky, B., Shedlofsky, S., et al. (2003) Elevation of Ceramide in Serum Lipoproteins during Acute Phase Response in Humans and Mice: Role of Serine-Palmitoyl Transferase. Archives of Biochemistry and Biophysics, 419, 120-128. http://dx.doi.org/10.1016/j.abb.2003.08.031

[130] Nikolova-Karakashian, M.N. (2002) CHAPTER 15, Ceramide in Serum Lipoproteins: Function and Regulation of Metabolism. In: Futerman, A.H., Ed., Ceramide Signaling, Eurekah.com and Kluwer Academic/Plenum Publishers, New 
York.

[131] Hanada, K., Kumagai, K., Tomishige, N. and Kawano, M. (2007) CERT and Intracellular Trafficking of Ceramide. Biochimica et Biophysica Acta (BBA), Molecular and Cell Biology of Lipids, 1771, 644-653. http://dx.doi.org/10.1016/j.bbalip.2007.01.009

[132] Pinto, S.N., Silva, L.C., Futerman, A.H. and Prieto, M. (2011) Effect of Ceramide Structure on Membrane Biophysical Properties: The Role of Acyl Chain Length and Unsaturation. Biochimica et Biophysica Acta (BBA) , Biomembranes, 1808, 2753-2760. http://dx.doi.org/10.1016/j.bbamem.2011.07.023

[133] Huuskonen, J., Olkkonen, V.M., Jauhiainen, M., Metso, J., Somerharju, P. and Ehnholm, C. (1996) Acyl Chain and Headgroup Specificity of Human Plasma Phospholipid Transfer Protein. Biochimica et Biophysica Acta (BBA), Lipids and Lipid Metabolism, 1303, 207-214. http://dx.doi.org/10.1016/0005-2760(96) 00103-8

[134] Kontush, A., Therond, P., Zerrad, A., Couturier, M., Négre-Salvayre, A., de Souza, J.A., et al. (2007) Preferential Sphingosine-1-Phosphate Enrichment and Sphingomyelin Depletion Are Key Features of Small Dense HDL3 Particles: Relevance to Antiapoptotic and Antioxidative Activities. Arteriosclerosis Thrombosis, Thrombosis, and Vascular Biology, 27, 1843-1849. http://dx.doi.org/10.1161/ATVBAHA.107.145672

[135] Takabe, K., Paugh, S.W., Milstien, S. and Spiegel, S. (2008) “Inside-Out” Signaling of Sphingosine-1-Phosphate: Therapeutic Targets. Pharmacological Review, 60, 181-195. http://dx.doi.org/10.1124/pr.107.07113

[136] Yu, Y., Guo, S., Feng, Y., Feng, L., Cui, Y., Song, G., et al. (2014) Phospholipid Transfer Protein Deficiency Decreases the Content of S1P in HDL via the Loss of Its Transfer Capability. Lipids, 49, 183-190. http://dx.doi.org/10.1007/s11745-013-3850-y

[137] Pfreiger, F.W. and Ungerer, N. (2011) Cholesterol Metabolism in Neurons and Astrocytes. Progress in Lipid Research, 50, 357-371. http://dx.doi.org/10.1016/j.plipres.2011.06.002

[138] Pfrieger, F.W. (2003) Outsourcing in the Brain: Do Neurons Depend on Cholesterol Delivery by Astrocytes? BioEssays, 25, 72-78. http://dx.doi.org/10.1002/bies.10195

[139] Smith, I.F., Green, K.N. and LaFerla, F.M. (2005) Calcium Dysregulation in Alzheimer’s Disease: Recent Advancesgained from Genetically Modified Animals. Cell Calcium, 38, 427-437. http://dx.doi.org/10.1016/j.ceca.2005.06.021

[140] Hansson, E. and Rönnbäck, L.L. (2003) Glial Neuronal Signaling in the Central Nervous System. The FASEB Journal, 17, 341-348. http://dx.doi.org/10.1096/fj.02-0429rev

[141] Dringen, R., Gutterer, J.M. and Hirrlinger, J. (2000) Glutathione Metabolism in Brain. Metabolic Interaction between Astrocytes and Neurons in the Defense against Reactive Oxygen Species. European Journal of Biochemistry, 267, 4912-4916. http://dx.doi.org/10.1046/j.1432-1327.2000.01597.X

[142] Chen, Y., Vartiainen, N.E., Ying, W., Chan, P.H., Koistinaho, J. and Swanson, R.A. (2001) Astrocytes Protect Neurons from Nitric Oxide Toxicity by a Glutathione-Dependent Mechanism. Journal of Neurochemistry, 77, 1601-1610. http://dx.doi.org/10.1046/j.1471-4159.2001.00374.x

[143] Thal, D.R. (2012) The Role of Astrocytes in Amyloid $\beta$-Protein Toxicity and Clearance. Experimental Neurology, 236, 1-5. http://dx.doi.org/10.1016/j.expneurol.2012.04.021

[144] Meyer, R.P., Knotha, R., Schiltzb, E. and Volk, B. (2001) Possible Function of Astrocyte Cytochrome P450 in Control of Xenobiotic Phenytoin in the Brain: In Vitro Studies on Murine Astrocyte Primary Cultures. Experimental Neurology, 167, 376-384. http://dx.doi.org/10.1006/exnr.2000.7553

[145] Volk, B., Meyer, R.P. and Knoth, R. (2004) Chapter 4. Function of Astrocyte Cytochrome P450 in Control of Xenobiotic Metabolism. In: Aschner, M. and Lucio, G.C., Eds., The Role of Glia in Neurotoxicity, 2nd Edition, CRC Press, Boca Raton, 61-72.

[146] Harris, F.M., Tesseur, I., Brecht, W.J., Xu, Q., Mullendorff, K., Chang, S., et al. (2004) Astroglial Regulation of Apolipoprotein E Expression inNeuronal Cells. The Journal of Biological Chemistry, 279, 3862-3868. http://dx.doi.org/10.1074/jbc.M309475200

[147] Gee, J.R. and Keller, J.N. (2005) Astrocytes: Regulation of Brain Homeostasis via Apolipoprotein E. The International Journal Biochemistry \& Cell Biology, 37, 1145-1150. http://dx.doi.org/10.1016/j.biocel.2004.10.004

[148] Wang, X., Ciraolob, G., Morrisb, R. and Gruenstein, E. (1997) Identification of a Neuronal Endocytic Pathway Activated by an Apolipoprotein E (apoE) Receptor Binding Peptide. Brain Research, 778, 6-15. http://dx.doi.org/10.1016/S0006-8993(97) 00877-9

[149] Misra, U.K., Adlakha, C.L., Gawdi, G., McMillian, M.K., Pizzo, S.V. and Laskowitz, D.T. (2001) Apolipoprotein E and Mimetic Peptide Initiate a Calcium-Dependent Signaling Response in Macrophages. Journal of Leukocyte Biology, 70, 677-683.

[150] Morikawa, M., Fryera, J.D., Sullivanb, P.M., Christophera, E.A., Wahrlea, S.E., DeMattos, R.B., et al. (2005) Produc- 
tion and Characterization of Astrocyte-Derived Human Apolipoprotein E Isoforms from Immortalized Astrocytes and Their Interactions with Amyloid-Beta. Neurobiology of Disease, 19, 66-76.

http://dx.doi.org/10.1016/j.nbd.2004.11.005

[151] Sato, K., Malchinkhuu, E., Horiuchi, Y., Mogi, C., Tomura, H., Tosaka, M., et al. (2007) Critical Role of ABCA1 Transporter in Sphingosine 1-Phosphate Release from Astrocytes. Journal of Neurochemistry, 103, 2610-2619.

[152] Jänis, M.T., Metso, J., Lankinen, H., Strandin, T., Olkkonen, V.M., Rye, K.A., et al. (2005) Apolipoprotein E Activates the Low-Activity form of Human Phospholipid Transfer Protein. Biochemical and Biophysical Research Communications, 331, 333-340. http://dx.doi.org/10.1016/j.bbrc.2005.03.164

[153] Tan, K.C., Shiu, S.W.M., Wong, Y., Wong, W.K. and Tam, S. (2006) Plasma Apolipoprotein E Concentration Is an Important Determinant of Phospholipid Transfer Protein Activity in Type 2 Diabetes Mellitus. Diabetes/Metabolism Research and Review, 22, 307-312. http://dx.doi.org/10.1002/dmrr.616

[154] Oram, J.F., Wolfbauer, G., Tang, C., Davidson, W.S. and Albers, J.J. (2008) An Amphipathic Helical Region of the N-Terminal Barrel of Phospholipid Transfer Protein Is Critical for ABCA1-Dependent Cholesterol Efflux. Journal of Biological Chemistry, 283, 11541-11549. http://dx.doi.org/10.1074/jbc.M800117200

[155] Lalanne, F., Motta, C., Pafumi, Y., Lairon, D. and Ponsin, G. (2001) Modulation of the Phospholipid Transfer Protein-Mediated Transfer of Phospholipids by Diacylglycerols. The Journal of Lipid Research, 42, 142-149.

[156] Gabuzda, D., Busciglio, J. and Yankner, B.A. (1993) Inhibition of Beta-Amyloid Production by Activation of Protein Kinase C. Journal of Neurochemistry, 61, 2326-2329. http://dx.doi.org/10.1111/j.1471-4159.1993.tb07479.x

[157] Tanabe, F., Nakajima, T. and Ito, M. (2014) Involvement of Diacylglycerol Produced by Phospholipase D Activation in $\mathrm{A} \beta$-Induced Reduction of SAPP $\alpha$ Secretion in SH-SY5Y Neuroblastoma Cells. Biochemistry and Biophysics Research Communication, 446, 933-939. http://dx.doi.org/10.1016/j.bbrc.2014.03.038

[158] Mungenast, A.E. (2011) Diacylglycerol Signaling Underlies Astrocytic ATP Release. Neural Plasticity, 2011, Article ID: 537659. http://dx.doi.org/10.1155/2011/537659

[159] Garwood, C.J., Pooler, A.M., Atherton, J., Hanger, D.P. and Noble, W. (2011) Astrocytes Are Important Mediators of A $\beta$-Inducedneurotoxicity and Tau Phosphorylation in Primary Culture. Cell Death and Disease, 2, e167. http://dx.doi.org/10.1038/cddis.2011.50

[160] Nagele, R.G., D’Andrea, M.R., Lee, H., Venkataraman, V. and Wang, H.Y. (2003) Astrocytes Accumulate A Beta 42 and Give Rise to Astrocytic Amyloid Plaques in Alzheimer Disease Brains. Brain Research, 971, 197-209. http://dx.doi.org/10.1016/S0006-8993(03) 02361-8

[161] Wyss-Coray, T., Loike, J.D., Brionne, T.C., Lu, E., Anankov, R., Yan, F., et al. (2003) Adult Mouse Astrocytes Degrade Amyloid- $\beta$ in Vitro and in Situ. Nature Medicine, 9, 453-457, http://dx.doi.org/10.1038/nm838

[162] Canepa, E., Borghi, R., Viña, J., Traverso, N., Gambini, J., Domenicotti, C., et al. (2011) Cholesterol and Amyloid- $\beta$ : Evidence for a Cross-Talk between Astrocytes and Neuronal Cells. Journal of Alzheimer's Disease, 25, 645-653.

[163] Ghering, A.B. and Davidson, W.S. (2006) Ceramide Structural Features Required to Stimulate ABCA1-Mediated Cholesterol Efflux to Apolipoprotein A-I. Journal of Lipid Research, 47, 2781-2788. http://dx.doi.org/10.1194/jlr.M600380-JLR200

[164] Witting, S.R., Maiorano, N. and Davidson, W.S. (2003) Ceramide Enhances Cholesterol Efflux to Apolipoprotein A-I by Increasing the Cell Surface Presence of ATP-Binding Cassette Transporter A1.The Journal of Biological Chemistry, 278, 40121-40127. http://dx.doi.org/10.1074/jbc.M305193200

[165] Martins, I.J., Lim, W.L.F., Wilson, A.C., Laws, S.M. and Martins, R.N. (2013) The Acceleration of Aging and Alzheimer's Disease through the Biological Mechanisms Behind Obesity and Type II Diabetes. Health, 5, 913-992. http://dx.doi.org/10.4236/health.2013.55121

[166] Lim, F.L., Lam, S.M., Shui, G., Mondal, A., Ong, D., Duan, X., et al. (2013) Effects of a High-Fat, High-Cholesterol Diet on Brain Lipid Profiles in Apolipoprotein E $\varepsilon 3$ and $\varepsilon 4$ Knock-In Mice. Neurobiology of Aging, 34, 2217-2224. http://dx.doi.org/10.1016/j.neurobiolaging.2013.03.012

[167] Frisardi, V., Panza, F., Seripa, D., Farooqui, T. and Farooqui, A.A. (2011) Glycerophospholipids and Glycerophospholipid-Derived Lipid Mediators: A Complex Meshwork in Alzheimer’s Disease Pathology. Progress in Lipid Research, 50, 313-330. http://dx.doi.org/10.1016/j.plipres.2011.06.001

[168] Caggiula, A.W. and Mustad, V.A. (1997) Effects of Dietary Fat and Fatty Acids on Coronary Artery Disease Risk and total and Lipoprotein Cholesterol Concentrations: Epidemiologic Studies. American Journal of Clinical Nutrition, 65, 1597S-1610S.

[169] Kris-Etherton, P.M. and Yu, S. (1997) Individual Fatty Acid Effects on Plasma Lipids and Lipoproteins: Human Studies. American Journal Clinical Nutrition, 65, 1628S-1644S.

[170] Kris-Etherton, P.M., Yu, S., Etherton, T.D., Morgan, R., Moriarty, K. and Shaffer, D. (1997) Fatty Acids and Progres- 
sion of Coronary Artery Disease. American Journal of Clinical Nutrition, 65, 1088-1090.

[171] Gill, J.M. and Sattar, N. (2009) Ceramides: A New Player in the Inflammation-Insulin Resistance Paradigm? Diabetologia, 52, 2475-2477. http://dx.doi.org/10.1007/s00125-009-1546-X

[172] Espenshade, P.J. (2006) SREBPs: Sterol Regulated Transcription Factors. Journal of Cell Science, 119, 973-976.

[173] Spady, D.K., Woollett, L.A. and Dietschy, J.M. (1993) Regulation of Plasma LDL-Cholesterol Levels by Dietary Cholesterol and Fatty Acids. Annual Reveiw Nutrition, 13, 355-381.

http://dx.doi.org/10.1146/annurev.nu.13.070193.002035

[174] Worgall, T.S., Juliano, R.A., Seo, T. and Deckelbaum, R.J. (2004) Ceramide Synthesis Correlates with the Posttranscriptional Regulation of the Sterol-Regulatory Element-Binding Protein. Arteriosclerosis, Thrombosis, and Vascular Biology, 24, 943-948. http://dx.doi.org/10.1161/01.atv.0000125703.20434.4d

[175] Ascherio, A., Katan, M.B., Zock, P.L., Stampfer, M.J. and Willett, W.C. (1994) Trans Fatty Acids and Coronary Heart Disease. The New England Journal of Medicine, 340, 1994-1998. http://dx.doi.org/10.1056/NEJM199906243402511

[176] Morris, M.C., Evans, D.A., Bienias, J.L., Tangney, C.C., Bennett, D.A., Aggarwal, N., et al. (2003) Dietary Fats and the Risk of Incident Alzheimer Disease. Archives of Neurology, 60, 194-200. http://dx.doi.org/10.1001/archneur.60.2.194

[177] Bowman, G.L., Silbert, L.C., Howieson, D., Dodge, H.H., Traber, M.G., Frei, B., et al. (2012) Nutrient Biomarker Patterns, Cognitive Function, and MRI Measures of Brain Aging. Neurology, 78, 241-249. http://dx.doi.org/10.1212/WNL.0b013e3182436598

[178] Mauger, J.F., Lichtenstein, A.H., Ausman, L.M., Jalbert, S.M., Jauhiainen, M., Ehnholm, C., et al. (2003) Effect of Different Forms of Dietary Hydrogenated Fats on LDL Particle Size. American Journal Clinical Nutrition, 78, 370-375.

[179] van Tol, A., Zock, P.L., van Gent, T., Scheek, L.M. and Katan, M. (1995) Dietary Trans Fatty Acids Increase Serum Cholesteryl Ester Transfer Protein Activity in Man. Atherosclerosis, 115, 129-134. http://dx.doi.org/10.1016/0021-9150(94) 05509-H

[180] Parks, J.S., Huggins, K.W., Gebre, A.K. and Burleson, E.R. (2000) Phosphatidylcholine Fluidity and Structure Affect Lecithin: Cholesterol Acyltransferase Activity. Journal of Lipid Research, 41, 546-553.

[181] Khan, S.A. and Heuvel, J.P.V. (2003) Reviews: Current Topicsrole of Nuclear Receptors in the Regulation of Gene Expression by Dietary Fatty Acids (Review). The Journal of Nutritional Biochemistry, 14, 554-567. http://dx.doi.org/10.1016/S0955-2863(03) 00098-6

[182] Heuvel, J.P.V. (2009) Cardiovascular Disease-Related Genes and Regulation by Diet. Current Atherosclerosis Reports, 11, 448-455. http://dx.doi.org/10.1007/s11883-009-0067-x

[183] Heuvel, J.P.V. (2004) Diet, Fatty Acids, and Regulation of Genes Important for Heart Disease. Current Atherosclerosis Reports, 6, 432-440. http://dx.doi.org/10.1007/s11883-004-0083-9

[184] Cantó, C., Jiang, L.Q., Deshmukh, A.S., Mataki, C., Coste, A., Lagouge, M., Zierath, J.R., et al. (2010) Interdependence of AMPK and SIRT1 for Metabolic Adaptation to Fasting and Exercise in Skeletal Muscle. Cell Metabolism, 11, 213-219. http://dx.doi.org/10.1016/j.cmet.2010.02.006

[185] Wang, J., Fivecoata, H., Hoa, L., Pana, Y., Linga, E.and Pasinetti, G.M. (2010) The Role of Sirt1: At the Crossroad between Promotion of Longevity and Protection against Alzheimer's Disease Neuropathology. Biochimica et Biophysica Acta (BBA), Proteins and Proteomics, 1804, 1690-1694. http://dx.doi.org/10.1016/j.bbapap.2009.11.015

[186] Donmez, G., Wang, D., Cohen, D.E. and Guarente, L. (2010) SIRT1 Suppresses Beta-Amyloid Production by Activating the Alpha-Secretase Gene ADAM10. Cell, 142, 320-332. http://dx.doi.org/10.1016/j.cell.2010.06.020

[187] Xu, F., Gao, Z., Zhang, J., Rivera, C.A., Yin, J., Weng, J., et al. (2010) Lack of SIRT1 (Mammalian Sirtuin 1) Activity Leads to Liver Steatosis in the SIRT1 ${ }^{+} \Gamma$ Mice: A Role of Lipid Mobilization and Inflammation. Endocrinology, 151, 2504-2514. http://dx.doi.org/10.1210/en.2009-1013

[188] Purushotham, A., Xu, Q. and Li, X. (2012) Systemic SIRT1 Insufficiency Results in Disruption of Energy Homeostasis and Steroid Hormone Metabolism upon High-Fat-Diet Feeding. The FASEB Journal, 26, 656-667. http://dx.doi.org/10.1096/fj.11-195172

[189] Martins, I.J., Wilson, A.C., Lim, W.L.F., Laws, S.M., Fuller, S.J. and Martins, R.N. (2012) Sirtuin-1 Mediates the Obesity Induced Risk of Common Degenerative Diseases: Alzheimer's Disease, Coronary Artery Disease and Type 2 Diabetes. Health, 4, 1448-1456. http://dx.doi.org/10.4236/health.2012.412A209

[190] Honig, L.S., Tang, M.X., Albert, S., Costa, R., Luchsinger, J., Manly, J., et al. (2003) Stroke and the Risk of Alzheimer Disease. Archives of Neurology, 60, 1707-1712. http://dx.doi.org/10.1001/archneur.60.12.1707

[191] Albi, E., Michelli, M. and Magni, M.P.V. (1996) Phospholipids and Nuclear RNA. Cell Biology International, 20, 407412. http://dx.doi.org/10.1006/cbir.1996.0051 
[192] Zhdanov, R.I., Struchkov, V.A., Dyabina, O. and Strazhevskaya, N.B. (2001) Chromatin-Bound Cardiolipin: The Phospholipid of Proliferation.Cytobios, 106, 55-61.

[193] Albi, E. and Magni, M.P.V. (2004) The Role of Intranuclear Lipids. Biology of the Cell, 96, 657-667. http://dx.doi.org/10.1016/j.biolcel.2004.05.004

[194] Hunt, A.N. (2006) Dynamic Lipidomics of the Nucleus. Journal of Cellular Biochemistry, 97, 244-251. http://dx.doi.org/10.1002/jcb.20691

[195] Albi, E. and Villani, M. (2009) Nuclear Lipid Microdomains Regulate Cell Function. Communicative \& Integrative Biology, 2, 23-24. http://dx.doi.org/10.4161/cib.2.1.7376

[196] Cascianelli, G., Villani, M., Tosti, M., Marini, F., Bartoccini, E., Magni, M.V., et al. (2008) Lipid Microdomains in Cell Nucleus. Molecular Biology of the Cell, 19, 5289-5295. http://dx.doi.org/10.1091/mbc.E08-05-0517

[197] Bazan, N.G. (2005) Synaptic Signaling by Lipids in the Life and Death of Neurons. Molecular Neurobiology, 31, 219230. http://dx.doi.org/10.1385/MN:31:1-3:219

[198] Pope, S., Land, J.M. and Heales, S.J. (2008) Oxidative Stress and Mitochondrial Dysfunction in Neurodegeneration; Cardiolipin a Critical Target? Biochimica et Biophysica Acta (BBA), Bioenergetics, 1777, 794-799. http://dx.doi.org/10.1016/j.bbabio.2008.03.011

[199] Kirkland, R.A., Adibhatla, R.M., Hatcher, J.F. and Franklin, J.L. (2002) Loss of Cardiolipin and Mitochondria during Programmed Neuronal Death: Evidence of a role for Lipid Peroxidation and Autophagy. Neuroscience, 115, 587-602. http://dx.doi.org/10.1016/S0306-4522(02) 00512-2

[200] Pébay, A., Toutant, M., Prémont, J., Calvo, C.F., Venance, L., Cordier, J., et al. (2001) Sphingosine-1-Phosphate Induces Proliferation of Astrocytes: Regulation by Intracellular Signalling Cascades. European Journal of Neuroscience, 13, 2067-2076. http://dx.doi.org/10.1046/j.0953-816x.2001.01585.x

[201] Lucki, N.C. and Sewer, M.B. (2012) Nuclear Sphingolipid Metabolism. Annual Review of Physiology, 74, $131-151$. http://dx.doi.org/10.1146/annurev-physiol-020911-153321

[202] Spohr, T.C., Dezonne, R.S., Nones, J., Souza, C., Einicker-Lamas, M., Gomes, F.C.A., et al. (2012) Sphingosine 1-Phosphate-Primed Astrocytes Enhance Differentiation of Neuronal Progenitor Cells. Journal of Neuroscience Research, 90, 1892-902. http://dx.doi.org/10.1002/jnr.23076

[203] Stipursky, J., Spohr, T.C., Sousa, V.O. and Gomes, F.C.A. (2012) Neuron-Astroglial Interactions in Cell-Fate Commitment and Maturation in the Central Nervous System. Neurochemistry Research, 37, 2402-2418. http://dx.doi.org/10.1007/s11064-012-0798-X

[204] Buccoliero, R. and Futerman, A.H. (2003) The Roles of Ceramide and Complex Sphingolipids in Neuronal Cell Function. Pharmacology Research, 47, 409-419. http://dx.doi.org/10.1016/S1043-6618(03) 00049-5

[205] Chun-Xia, Y. and Tschöp, M.H. (2012) Brain-Gut-Adipose-Tissue Communication Pathways at a Glance. Disease Models \& Mechanisms, 5, 583-587. http://dx.doi.org/10.1242/dmm.009902

[206] Caspi, L., Wang, P.Y and Lam, T.K. (2007) A Balance of Lipid-Sensing Mechanismsin the Brain and Liver. Cell Metabolism, 6, 99-104. http://dx.doi.org/10.1016/j.cmet.2007.07.005

[207] Vacca, M., Degirolamo, C., Mariani-Costantini, R., Palasciano, G. and Moschetta, A. (2011) Lipid-Sensing Nuclear Receptors in the Pathophysiology and Treatment of the Metabolic Syndrome. Wiley Interdisciplinary Reviews: Systems Biology and Medicine, 3, 562-587. http://dx.doi.org/10.1002/wsbm.137

[208] Beaven, S.W. and Tontonoz, P. (2006) Nuclear Receptors in Lipid Metabolism: Targeting the Heart of Dyslipidemia. Annual Review of Medicine, 57, 313-329. http://dx.doi.org/10.1146/annurev.med.57.121304.131428

[209] Ferrari, A., Fiorino, E., Giudici, M., Gilardi, F., Galmozzi, A., Mitro, N., et al. (2012) Linking Epigenetics to Lipid Metabolism: Focus on Histone Deacetylases. Molecular Membrane Biology, 29, 257-266. http://dx.doi.org/10.3109/09687688.2012.729094

[210] Goetzl, E.J. (2007) Diverse Pathways for Nuclear Signaling by G Protein-Coupled Receptors and Their Ligands. The FASEB Journal, 21, 638-642. http://dx.doi.org/10.1096/fj.06-6624hyp

[211] Alemany, R., Perona, J.S., Sánchez-Dominguez, J.M., Montero, E., Cañizares, J., Bressani, R., Escribá, P.V., et al. (2007) G Protein-Coupled Receptor Systems and Their Lipid Environment in Health Disorders during Aging. Biochimica et Biophysica Acta (BBA, Biomembranes, 1768, 964-975. http://dx.doi.org/10.1016/j.bbamem.2006.09.024

[212] Takahashi, T., Kajikawa, Y. and Tsujimoto, T. (1998) G-Protein-Coupled Modulation of Presynaptic Calcium Currents and Transmitter Release by a GABAB Receptor. The Journal of Neuroscience, 18, 3138-3146.

[213] Zamponia, G.W. and Currie, K.P.M. (2013) Regulation of $\mathrm{Ca}_{\mathrm{V}} 2$ Calcium Channels by G Protein Coupled Receptors. Biochimica et Biophysica Acta (BBA, Biomembranes, 1828, 1629-1643.

http://dx.doi.org/10.1016/j.bbamem.2012.10.004 
[214] Riboni, L., Prinetti, A., Bassi, R. and Tettamanti, G. (1994) Formation of Bioactive Sphingoid Molecules from Exogenous Sphingomyelin in Primary Cultures of Neurons and Astrocytes. FEBS Letters, 352, 323-326. http://dx.doi.org/10.1016/0014-5793(94) 00984-8

[215] Reimertz, C., Reimertz, C., Münstermann, G., Kögel, D. and Prehn, J.H.M. (2002) Ceramide-Induced Apoptosis of D283 Medulloblastoma Cells Requires Mitochondrial Respiratory Chain Activity but Occurs Independently of Caspases and Is Not Sensitive to Bcl-xL Overexpression. Journal of Neurochemistry, 82, 482-494. http://dx.doi.org/10.1046/j.1471-4159.2002.01007.x

[216] Won, J.S, Singh, A.K. and Singh, I. (2007) Lactosylceramide: A Lipid Second Messenger in Neuroinflammatory Disease. Journal of Neurochemistry, 103, 180-191. http://dx.doi.org/10.1111/j.1471-4159.2007.04822.x

[217] Hannun, Y.A. and Obeid, L.M. (2008) Principles of Bioactive Lipid Signalling: Lessons from Sphingolipids. Nature Reviews Molecular Cell Biology, 9, 139-150. http://dx.doi.org/10.1038/nrm2329

[218] Spiegel, S. and Milstien, S. (2002) Sphingosine 1-Phosphate, a Key Cell Signaling Molecule. The Journal of Biological Chemistry, 277, 25851-25854. http://dx.doi.org/10.1074/jbc.R200007200

[219] Walter, L., Franklin, A., Witting, A., Möller, T. and Stella, N. (2002) Astrocytes in Culture Produce Anandamide and Other Acylethanolamides. Journal of Biological Chemistry, 277, 20869-20876. http://dx.doi.org/10.1074/jbc.M110813200

[220] Rao, R.P., Vaidyanathan, N., Rengasamy, M., Oommen, A.M., Somaiya, N. and Jagannath, M.R. (2013) Sphingolipid Metabolic Pathway: An Overview of Major Roles Played in Human Diseases. Journal of Lipids, 2013, Article ID: 178910. http://dx.doi.org/10.1155/2013/178910

[221] Ariga, T., Jarvis, W.D. and Yu, R.K. (1998) Role of Sphingolipid-Mediated Cell Death in Neurodegenerative Diseases. Journal of Lipid Research, 39, 1-16.

[222] Nishimura, H., Akiyama, T., Irei, I., Hamazaki, S. and Sadahira, Y. (2010) Cellular Localization of Sphingosine-1-Phosphate Receptor 1 Expression in the Human Central Nervous System. Journal of Histochemistry Cytochemistry, 58, 847-856.

[223] Burrows, E.L. and Bird, R.J. (2012) Obesity-Associated Steatotic Liver Exhibits Aberrant or Altered Sphingolipid Composition and Preferentially Accumulates Ceramide Species Containing Long Chain Fatty Acids. Health, 4, 1578-1587. http://dx.doi.org/10.4236/health.2012.412A226

[224] Samad, F., et al. (2006) Altered Adipose and Plasma Sphingolipid Metabolism in Obesity: A Potential Mechanism for Cardiovascular and Metabolic Risk. Diabetes, 55, 2579-2587. http://dx.doi.org/10.2337/db06-0330

[225] Kowalski, G.M., et al. (2013) Plasma Sphingosine-1-Phosphate Is Elevated in Obesity. PLoS ONE, 8, e72449. http://dx.doi.org/10.1371/journal.pone.0072449

[226] Dinkins, M., He, Q., Zhu, G., Poirier, C., Campbell, A., Mayer-Proschel, M., et al. (2012) Astrocytes Secrete Exosomes Enriched with Proapoptotic Ceramide and Prostate Apoptosis Response 4 (PAR-4) : Potential Mechanism of Apoptosis Induction in Alzheimer Disease (AD).Journal of Biological Chemistry, 287, 21384-21395.

[227] Navarrete, M. and Araque, A. (2008) Endocannabinoids Mediate Neuron-Astrocyte Communication. Neuron, 57, 883893. http://dx.doi.org/10.1016/j.neuron.2008.01.029

[228] Berghuis, P., Dobszay, M.B., Wang, X., Spano, S., Ledda, F., Sousa, K.M., et al. (2005) Endocannabinoids Regulate Interneuron Migration and Morphogenesis by Transactivating the TrkB Receptor. Proceedings of the National Academy of Sciences of the United States of America, 102, 19115-19120. http://dx.doi.org/10.1073/pnas.0509494102

[229] Diana, M.A and Bregestovski, P. (2005) Calcium and Endocannabinoids in the Modulation of Inhibitory Synaptic Transmission. Cell Calcium, 37, 497-505. http://dx.doi.org/10.1016/j.ceca.2005.01.020

[230] Kuo, J. and Ikeda, S.R. (2004) Endocannabinoids Modulate N-Type Calcium Channels and G-Protein-Coupled Inwardly Rectifying Potassium Channels via CB1 Cannabinoid Receptors Heterologously Expressed in Mammalian Neurons. Molecular Pharmacology, 65, 665-674. http://dx.doi.org/10.1124/mol.65.3.665

[231] Bosier, B., Bellocchio, L., Metna-Laurent, M., Soria-Gomez, E., Matias, I., Hebert-Chatelain, E., et al. (2013) Astroglial CB1 Cannabinoid Receptors Regulate Leptin Signalling in Mouse Brain Astrocytes. Molecular Mechanism, 2, 393-404.

[232] Kirkham, T.C. (2009) Cannabinoids and Appetite: Food Craving and Food Pleasure. International Review of Psychiatry, 21, 163-171.

[233] Lichtman, A.H. and Cravatt, B.F. (2005) Food for Thought: Endocannabinoid Modulation of Lipogenesis. The Journal of Clinical Investigation, 115, 1130-1133. http://dx.doi.org/10.1172/JCI25076

[234] Martins, I.J., et al. (2013) Anti-Oxidative Acyl CoA Cholesterol Acyltransferase Inhibitor AVASIMIBE Reduces the Impact of a High Cholesterol Diet on Brain Lipid Peroxidation in Mice. ADPD2013, Florence. www.kenes.com

[235] Petrosillo, P., Portincasab, P., Grattaglianob, I., Casanovaa, G., Materaa, M., Ruggiero, F.M., et al. (2007) Mitochon- 
drial Dysfunction in Rat with Nonalcoholic Fatty Liver: Involvement of Complex I, Reactive Oxygen Species and Cardiolipin. Biochimica Biophysica Acta (BBA), Bioenergetics, 1767, 1260-1267.

http://dx.doi.org/10.1016/j.bbabio.2007.07.011

[236] Sparagna, G.C., Chicco, A.J., Murphy, R.C., Bristow, M.R., Johnson, C.A., Rees, M.L., et al. (2007) Loss of Cardiac Tetralinoleoyl Cardiolipin in Human and Experimental Heart Failure. The Journal of Lipid Research, 48, 1559-1570. http://dx.doi.org/10.1194/jlr.M600551-JLR200

[237] Han, X., Yang, J., Yang, K., Zhao, Z., Abendschein, D.R. and Gross, R.W. (2007) Alterations in Myocardial Cardiolipin Content and Composition Occur at the Very Earliest Stages of Diabetes: A Shotgun Lipidomics Study. Biochemistry, 46, 6417-6428. http://dx.doi.org/10.1021/bi7004015

[238] Paradies, G., Petrosillo, G., Paradies, V. and Ruggiero, F.M. (2011) Mitochondrial Dysfunction in Brain Aging: Role of Oxidative Stress and Cardiolipin. Neurochemistry International, 58, 447-457. http://dx.doi.org/10.1016/j.neuint.2010.12.016

[239] Wiswedel, I., Gardemann, A., Storch, A., Peter, D. and Schild, L. (2010) Degradation of Phospholipids by Oxidative Stress-Exceptional Significance of Cardiolipin. Free Radical Research, 44, 135-145. http://dx.doi.org/10.3109/10715760903352841

[240] Demuro, A., Smith, M. and Parker, I. (2011) Single-Channel $\mathrm{Ca}^{2+}$ Imaging Implicates A $\beta 1-42$ Amyloid Pores in Alzheimer's Disease Pathology. Journal of Cell Biology, 195, 515-524. http://dx.doi.org/10.1083/jcb.201104133

[241] Short, B. (2011) Imaging $\beta$ Amyloid's Pore Performance: Study Visualizes Alzheimer's Disease-Related Peptides Forming Toxic Calcium Channels in the Plasma Membrane. Journal of Cell Biology, 195, 345. http://dx.doi.org/10.1083/jcb.1953if

[242] Walsh, P. and Sharpe, S. (2011) Structure-Toxicity Relationships of Amyloid Peptide Oligomers. In: Chang, R.C.C, Ed., Advanced Understanding of Neurodegenerative Diseases, InTech, Rijeka, Chapter 4.

[243] Merril, A.H. (1999) Regulation of Cytochrome P450 Expression by Sphingolipids. Chemistry and Physics Lipids, 102, 131-139. http://dx.doi.org/10.1016/S0009-3084(99) 00081-X

[244] Kim, Y.M., Park, T.S and Kim, S.G. (2013) The Role of Sphingolipids in Drug Metabolism and Transport. Expert Opinion on Drug Metabolic \&Toxicology, 9, 319-331. http://dx.doi.org/10.1517/17425255.2013.748749

[245] Osindea, M., Mullershausenb, F. and Deva, K.K. (2007) Phosphorylated FTY720 Stimulates ERK Phosphorylation in Astrocytes via S1P Receptors. Neuropharmacology, 52, 1210-1218. http://dx.doi.org/10.1016/j.neuropharm.2006.11.010

[246] Bradley, S.J. and Challiss, R.A. (2012) G Protein-Coupled Receptor Signalling in Astrocytes in Health and Disease: A Focus on Metabotropic Glutamate Receptors. Biochemistry Pharmacology, 84, 249-259. http://dx.doi.org/10.1016/j.bcp.2012.04.009

[247] Vassart, G.and Costagliola, S. (2011) G Protein-Coupled Receptors: Mutations and Endocrine Diseases. Nature Review Endocrinology, 7, 362-372. http://dx.doi.org/10.1038/nrendo.2011.20

[248] Gobeil, F., Fortier, A., Zhu, T., Bossolasco, M., Leduc, M., Grandbois, M., et al. (2006) G-Protein-Coupled Receptors Signalling at the Cell Nucleus: An Emerging Paradigm. Canadian Journal of Physiology Pharmacology, 84, 287-297. http://dx.doi.org/10.1139/y05-127

[249] Erol, A. (2008) An Integrated and Unifying Hypothesis for the Metabolic Basis of Sporadic Alzheimer’s Disease. Journal of Alzheimer's Disease, 13, 241-253.

[250] Hsuchou, H., He, Y., Kastin, A.J., Tu, H., Markadakis, E.N., Rogers, R.C., et al. (2009) Obesity Induces Functional Astrocytic Leptin Receptors in Hypothalamus. Brain, 132, 889-902. http://dx.doi.org/10.1093/brain/awp029

[251] Chowen, J.A., Argente, J. and Horvath, T.L. (2013) Uncovering Novel Roles of Nonneuronal Cells in Body Weight Homeostasis and Obesity. Endocrinology, 154, 3001-3007. http://dx.doi.org/10.1210/en.2013-1303

[252] García-Cáceres, C., Fuente-Martín, E., Argente, J.and Chowen, J.A. (2012) Emerging Role of Glial Cells in the Control of Body Weight. Molecular Metabolism, 1, 37-46. http://dx.doi.org/10.1016/j.molmet.2012.07.001

[253] Lee, E.B. and Ahima, R.S. (2012) Alteration of Hypothalamic Cellular Dynamics in Obesity. The Journal of Clinical Investigation, 122, 22-25. http://dx.doi.org/10.1172/JCI61562

[254] Levin, B.E., Magnan, C., Dunn-Meynell, A. and Le Foll, C. (2011) Metabolic Sensing and the Brain: Who, What, Where, and How? Endocrinology, 152, 2552-2557. http://dx.doi.org/10.1210/en.2011-0194

[255] García-Cáceres, C., Yi, C.X. and Tschöp, M.H. (2013) Hypothalamic Astrocytes in Obesity. Endocrinology and Metabolism Clinical of North America, 42, 57-66. http://dx.doi.org/10.1016/j.ecl.2012.11.003

[256] Fuente-Martín, E., García-Cáceres, C., Granado, M., de Ceballos, M.L., Sánchez-Garrido, M.Á., Sarman, B., et al. (2012) Leptin Regulates Glutamate and Glucose Transporters in Hypothalamic Astrocytes. The Journal of Clinical Investigation, 122, 3900-3913. http://dx.doi.org/10.1172/JCI64102 
[257] Sheridan, P.A. (2010) Obesity and Microglial Activation: Potential for Synergism in Neurodegenerative Diseases. The FASEB Journal (Meeting Abstract Supplement), 326, 24.

[258] Thaler, J.P., et al. (2011) Rapid Onset of Hypothalamic Inflammation, Reactive Gliosis and Microglial Accumulation during High-Fat Diet-Induced Obesity. Endocrinology Review, 32.

[259] Yi, C.X., Al-Massadia, O., Donelana, E., Lehtia, M., Webera, J., Ress, C., et al. (2012) Exercise Protects against High-Fat Diet-Induced Hypothalamic Inflammation. Physiology \& Behavior, 106, 485-490. http://dx.doi.org/10.1016/j.physbeh.2012.03.021

[260] Buckmana, L.B., Hasty, A.H., Flaherty, D.K., Buckman, C.T., Thompson, M.M., Matlock, B.K., et al. (2014) High-Fat Diet Induced Obesity Is Associated with CNS Recruitment of Monocytes with the Phenotype of Activated Microglia/Macrophage. Brain Behaviour and Immunity, 35, 33-42.

[261] Camargo N., Brouwers, J.F., Loos, M., Gutmann, D.H., Smit, A.B. and Verheijen, M.H.G. (2012) High-Fat Diet Ameliorates Neurological Deficits Caused by Defective Astrocyte Lipid Metabolism. TheFASEB Journal, 26, 4302-4315. http://dx.doi.org/10.1096/fj.12-205807

[262] Moraes, J.C., Coope, A., Morari, J., Cintra, D.E., Roman, E.A., Pauli, J.R., et al. (2009) High-Fat Diet Induces Apoptosis of Hypothalamic Neurons. PLOS ONE, 4, e5045. http://dx.doi.org/10.1371/journal.pone.0005045

[263] Gandhi G.K., Ball, K.K., Cruz, N.F. and Dienel, G.A. (2010) Hyperglycaemia and Diabetes Impair Gap Junctional Communication among Astrocytes. ASN Neurology, 2, e00030. http://dx.doi.org/10.1042/AN20090048

[264] Coleman, E.S., Dennisa, J.C., Bradena, T.D., Judda, R.L. and Posner, P. (2010) Insulin Treatment Prevents Diabetes-Induced Alterations Inastrocyte Glutamate Uptake and GFAP Content in Rats at 4 and 8Weeks of Diabetes Duration. Brain Research, 1306, 131-141. http://dx.doi.org/10.1016/j.brainres.2009.10.005

[265] Muranyi, M., Ding, C., He, Q.P., Lin, Y. and Li, P.A. (2006) Streptozotocin-Induced Diabetes Causes Astrocyte Death after Ischemia and Reperfusion Injury. Diabetes, 55, 349-355. http://dx.doi.org/10.2337/diabetes.55.02.06.db05-0654

[266] Montgomery, D.L. (1994) Astrocytes: Form, Functions, and Roles in Disease.Veterinary Pathology, 31, $145-167$. http://dx.doi.org/10.1177/030098589403100201

[267] Garcia-Segura, L.M., Chowen, J.A. and Naftolin, F. (1996) Endocrine Glia: Roles of Glial Cells in the Brain Actions of Steroid and Thyroid Hormones and in the Regulation of Hormone Secretion. Frontiers in Neuroendocrinology, 17, 180-211. http://dx.doi.org/10.1006/frne.1996.0005

[268] Theodosis, D.T., Piet, R., Poulain, D.A. and Oliet, S.H.R. (2004) Neuronal, Glial and Synaptic Remodeling in the Adult Hypothalamus: Functional Consequences and Role of Cell Surface and Extracellular Matrix Adhesion Molecules. Neurochemistry International, 45, 491-501. http://dx.doi.org/10.1016/j.neuint.2003.11.003

[269] Horvath, T.L., Sarmana, B., García-Cáceresd, C., Enriorie, P.J., Sotonyia, P., Shanabrough, M., et al. (2010) Synaptic Input Organization of the Melanocortin System Predicts Diet-Induced Hypothalamic Reactive Gliosis and Obesity. Proceedings of the National Academy of Sciences of the United States of America, 107, 14875-14880. http://dx.doi.org/10.1073/pnas.1004282107

[270] Thaler, J.P., Yi, C.X., Schur, E.A., Guyenet, S.J., Hwang, B.H., Dietrich, M.O., et al. (2012) Obesity Is Associated with Hypothalamic Injury in Rodents and Humans. The Journal of Clinical Investigation, 122, 153-162. http://dx.doi.org/10.1172/JCI59660

[271] Yi, C.X., Habegger, K.M., Chowen, J.A., Stern J. and Tschöp, M.H. (2011) A Role for Astrocytes in the Central Control of Metabolism. Neuroendocrinology, 93, 143-149. http://dx.doi.org/10.1159/000324888

[272] Sundvall, J., Saltevo, J., Niskanen, L., Kautiainen, H., Teittinen, J., Oksa, H., et al. (2011) Serum Calcium Level Is Associated with Metabolic Syndrome in the General Population: FIN-D2D Study. European Journal of Endocrinology, 165, 429-434. http://dx.doi.org/10.1530/EJE-11-0066

[273] Sun, G., Vasdev, S., Martin, G.R., Gadag, V. and Zhang, H. (2005) Altered Calcium Homeostasis Is Correlated with Abnormalities of Fasting Serum Glucose, Insulin Resistance, and Beta-Cell Function in the Newfoundland Population. Diabetes, 51, 3336-3339. http://dx.doi.org/10.2337/diabetes.54.11.3336

[274] Hagström, E., Hellman, P., Lundgren, E., Lind, L. and Ärnlöv, J. (2007) Serum Calcium Is Independently Associated with Insulin Sensitivity Measured with Euglycaemic-Hyperinsulinaemic Clamp in a Community-Based Cohort. Diabetologia, 50, 317-324. http://dx.doi.org/10.1007/s00125-006-0532-9

[275] Santos, L.C.D., Cintra, I.D.P., Fisberg, M. and Martini, L.A. (2008) Calcium Intake and Its Relationship with Adiposity and Insulin Resistance in Post-Pubertal Adolescents. Journal of Human Nutrition and Dietetics, 21, 109-116. http://dx.doi.org/10.1111/j.1365-277X.2008.00848.x

[276] Draznin, B. (1993) Cytosolic Calcium and Insulin Resistance. American Journal of Kidney Diseases, 21, S32-S38. http://dx.doi.org/10.1016/0272-6386(93) 70122-F

[277] Wang, X., Takano, T. and Nedergaard, M. (2009) Astrocytic Calcium Signaling: Mechanism and Implications for 
Functional Brain Imaging. Methods Molecular Biology, 489, 93-109.

http://dx.doi.org/10.1007/978-1-59745-543-5_5

[278] Dejeansa, N., Tajeddine, N., Beck, R., Verrax, J., Taper, H., Gailly, P., et al. (2010) Endoplasmic Reticulum Calcium Release Potentiates the ER Stress and Cell Death Caused by an Oxidative Stress in MCF-7 Cells. Biochemical Pharmacology, 79, 1221-1230. http://dx.doi.org/10.1016/j.bcp.2009.12.009

[279] Hammadi, M., Oulidi, A., Gackière, F., Katsogiannou, M., Slomianny, C., Roudbaraki, M., et al. (2013) Modulation of ER Stress and Apoptosis by Endoplasmic Reticulum Calcium Leak via Translocon during Unfolded Protein Response: Involvement of GRP78. The FASEB Journal, 27, 1600-1609. http://dx.doi.org/10.1096/fj.12-218875

[280] Schönthal, A.H. (2012) Endoplasmic Reticulum Stress: Its Role in Disease and Novel Prospects for Therapy. Scientifica (Cairo), 2012, Article ID: 857516. http://dx.doi.org/10.6064/2012/857516

[281] Xu, C., Bailly-Maitre, B. and Reed, J.C. (2005) Endoplasmic Reticulum Stress: Cell Life and Death Decisions. The Journal of Clinical Investigation, 115, 2656-2664. http://dx.doi.org/10.1172/JCI26373

[282] Fu, S., Yang, L., Li, P., Hofmann, O., Dicker, L., Hide, W., et al. (2011) Aberrant Lipid Metabolism Disrupts Calcium Homeostasis Causing Liver Endoplasmic Reticulum Stress in Obesity. Nature, 473, 528-531. http://dx.doi.org/10.1038/nature09968

[283] Högback, S., Leppimäki, P., Rudnäs, B., Björklund, S., Slotte, J.P. and Törnquist, K. (2003) Ceramide 1-Phosphate Increases Intracellular Free Calcium Concentrations in thyroid FRTL-5 Cells: Evidence for an Effect Mediated by Inositol 1, 4, 5-Trisphosphate and Intracellular Sphingosine 1-Phosphate. Biochemical Journal, 370, 111-119. http://dx.doi.org/10.1042/BJ20020970

[284] Kobrinsky, E., Spielman, A.I., Rosenzweig, S. and Marks, A.R. (1999) Ceramide Triggers Intracellular Calcium Release via the IP(3) Receptor in Xenopus laevis Oocytes. American Journal of Physiology, 277, C665-C672.

[285] Darios, F., Muriel, M.P., Khondiker, M.E., Brice, A. and Ruberg, M. (2005) Neurotoxic Calcium Transfer from Endoplasmic Reticulumto Mitochondria Is Regulated by Cyclin-Dependent Kinase5-Dependent Phosphorylation of Tau. The Journal of Neuroscience, 25, 4159-4168. http://dx.doi.org/10.1523/JNEUROSCI.0060-05.2005

[286] Sergeeva, M., Strokin, M. and Reiser, G. (2005) Regulation of Intracellular Calcium Levels by Polyunsaturated Fatty Acids, Arachidonic Acid and Docosahexaenoic Acid, in Astrocytes: Possible Involvement of Phospholipase $\mathrm{A}_{2}$. Reproduction Nutrition Development, 45, 633-646. http://dx.doi.org/10.1051/rnd:2005050

[287] Bonin, A. and Khan, N.A. (2000) Regulation of Calcium Signalling by Docosahexaenoic Acid in Human T-Cells. Implication of CRAC Channels. Journal of Lipid Research, 41, 277-284.

[288] Vreugdenhil, M., Bruehl, C., Voskuyl, R.A., Kang, J.X., Leaf, A. and Wadman, W.J. (1996) Polyunsaturated Fatty Acids Modulate Sodium and Calcium Currentsin CA1 Neurons. Proceedings of the National Academy of Sciences of the United States of America, 93, 12339-12365. http://dx.doi.org/10.1073/pnas.93.22.12559

[289] Venable, M.E., Zimmerman, G.A., McIntyre, T.M. and Prescott, S.M. (1993) Platelet-Activating Factor: A Phospholipid Autacoid with Diverse Actions. Journal of Lipid Research, 34, 691-702.

[290] Bazan, N.G. (1993) The Neuromessenger Platelet-Activating Factor in Plasticity and Neurodegeneration. Progress in Brain Research, 118, 281-291. http://dx.doi.org/10.1016/S0079-6123(08) 63215-X

[291] Kudolo, G.B., Bressler, P. and DeFronzo, R.A. (1997) Plasma PAF Acetylhydrolase in Non-Insulin Dependent Diabetes Mellitus and Obesity: Effect of Hyperinsulinemia and Lovastatin Treatment. Journal of Lipid Mediator and Cell Signalling, 17, 97-113. http://dx.doi.org/10.1016/S0929-7855(97) 00023-0

[292] Matsubara, S.M., Maruoka, S. and Katayose, S. (2002) Inverse Relationship between Plasma Adiponectin and Leptin Concentrations in Normal-Weight and Obese Women.European Journal of Endocrinology, 147, 173-180. http://dx.doi.org/10.1530/eje.0.1470173

[293] Ybarra, Y., Doñate, T., Jurado, J. and Pou, J.M. (2007) Primary Hyperparathyroidism, Insulin Resistance and Cardiovascular Disease. A Review. Nursing Clinics of North America, 42, 79-85. http://dx.doi.org/10.1016/j.cnur.2006.11.010

[294] Lee, E.B., Warmann, G., Dhir, R. and Ahima, R.S. (2011) Metabolic Dysfunction Associated with Adiponectin Deficiency Enhances Kainic Acid-Induced Seizure Severity. The Journal of Neuroscience, 31, 14361-14366. http://dx.doi.org/10.1523/JNEUROSCI.3171-11.2011

[295] Dezonne, R.S., Stipursky, J., Araujo, A.P., Nones, J., Pavão, M.S., Porcionatto, M., et al. (2013) Thyroid Hormone Treated Astrocytes Induce Maturation of Cerebral Cortical Neurons through Modulation of Proteoglycan Levels. Frontiers in Cell Neuroscience, 7, 125.

[296] Trentin, A.G. (2006) Thyroid Hormone and Astrocyte Morphogenesis. Journal of Endocrinology, 189, 189-197. http://dx.doi.org/10.1677/joe.1.06680

[297] Calzà, L. (2007) Thyroid Hormone Regulation of Neural and Oligodendrocyte Precursors in the Mature Brain: A Possibility for Remyelination and Neuroprotection. Endocrine Abstracts, 14, S2. 
[298] Perello, M. and Raingo, J. (2013) Leptin Activates Oxytocin Neurons of the Hypothalamic Paraventricular Nucleus in Both Control and Diet-Induced Obese Rodents. PLoS ONE, 8, e59625. http://dx.doi.org/10.1371/journal.pone.0059625

[299] Velmurugan, S., Russell, J.A. and Leng, G. (2013) Systemic Leptin Increases the Electrical Activity of Supraoptic Nucleus Oxytocin Neurones in Virgin and Late Pregnant Rats. Journal of Neuroendocrinology, 25, 383-390. http://dx.doi.org/10.1111/jne.12016

[300] Hoyda, T.D., Fry, M., Ahima, R.S. and Ferguson, A.V. (2007) Adiponectin Selectively Inhibits Oxytocin Neurons of the Paraventricular Nucleus of the Hypothalamus. Journal of Physiology, 585, 805-816. http://dx.doi.org/10.1113/jphysiol.2007.144519

[301] Ciosek, J. and Drobnik, J. (2004) Vasopressin and Oxytocin Release and the Thyroid Function. Journal of Physiology Pharmacology, 55, 423-441.

[302] Betsy, A., Binitha, M.P. and Sarita, S. (2013) Zinc Deficiency Associated with Hypothyroidism: An Overlooked Cause of Severe Alopecia. International Journal of Trichology, 5, 40-42. http://dx.doi.org/10.4103/0974-7753.114714

[303] Gee, J.R. and Keller, J.N. (2005) Astrocytes: Regulation of Brain Homeostasis via Apolipoprotein E. International Journal of Biochemistry Cell Biology, 37, 1145-1150. http://dx.doi.org/10.1016/j.biocel.2004.10.004

[304] Zhao, Z. and Michaely, P. (2009) The Role of Calcium in Lipoprotein Release by the Low-Density Lipoprotein Receptor. Biochemistry, 48, 7313-7324. http://dx.doi.org/10.1021/bi900214u

[305] Mulder, M., Koopmansb, G., Wassinkb, G., Al Mansourib, G., Simardb, M.L., Havekes, L.M., et al. (2007) LDL Receptor Deficiency Results in Decreased Cell Proliferation and Presynaptic Bouton Density in the Murine Hippocampus. Neuroscience Research, 59, 251-256. http://dx.doi.org/10.1016/j.neures.2007.07.004

[306] Faux, C.H. and Parnavela, J.G. (2007) The Role of Intracellular Calcium and RhoA in Neuronal Migration. Science's Signal Transduction Knowledge Environment, 2007, pe62.

[307] Rakic, P. and Komuro, H. (1995) The Role of Receptor/Channel Activity in Neuronal Cell Migration. Journal of Neurobiology, 26, 299-315. http://dx.doi.org/10.1002/neu.480260303

[308] Berger, M.J. (1998) Neuronal Calcium Signaling. Neuron, 21, 13-26. http://dx.doi.org/10.1016/S0896-6273(00) 80510-3

[309] Rosenberg, S.S. and Spitzer, N.C. (2011) Calcium Signaling in Neuronal Development. Cold Spring Harbour Perspective in Biology, 3, a004259. http://dx.doi.org/10.1101/cshperspect.a004259

[310] Fadeel, B. and Xue, D. (2009) The Ins and Outs of Phospholipid Asymmetry in the Plasma Membrane: Roles in Health and Disease. Critical Reviews in Biochemistry and Molecular Biology, 44, $264-277$. http://dx.doi.org/10.1080/10409230903193307

[311] Barenholz, Y. (2004) Sphingomyelin and Cholesterol: From Membrane Biophysics and Rafts to Potential Medical Applications. Subcellular Biochemistry, 37, 167-215. http://dx.doi.org/10.1007/978-1-4757-5806-1_5

[312] Viani, P., Cervato, G., Marchesini, S. and Cestaro, B. (1986) Fluorospectroscopic Studies of Mixtures of Distearoylphosphatidylcholine and Sulfatides with Defined Fatty Acid Compositions. Chemistry and Physics Lipids, 39, 41-51. http://dx.doi.org/10.1016/0009-3084(86) 90098-8

[313] Nybond, S., Björkqvist, J., Slotte, J.P. and Ramstedt, B. (2007) Sulfatide Exhibits Calcium Dependent Stabilization of Sphingomyelin/Cholesterol Domains in Bilayer Membranes. Chemistry and Physics of Lipids, 149, S36. http://dx.doi.org/10.1016/j.chemphyslip.2007.06.081

[314] Han, X., Holtzman, D.M., McKeel Jr., D.W., Kelley, J. and Morris, J.C. (2002) Substantial Sulfatide Deficiency and Ceramide Elevation in Very Early Alzheimer's Disease: Potential Role in Disease Pathogenesis. Journal of Neurochemistry, 82, 809-818. http://dx.doi.org/10.1046/j.1471-4159.2002.00997.x

[315] Han, X., Cheng, H., Fryer, J.D., Fagan, A.M. and Holtzman, D.M. (2003) Novel Role for Apolipoprotein E in the Central Nervous System. Modulation of Sulfatide Content. Journal of Biological Chemistry, 278, 8043-8051. http://dx.doi.org/10.1074/jbc.M212340200

[316] Berntson, Z., Hansson, E., Rönnbäck, L. and Fredman, P. (1998) Intracellular Sulfatide Expression in a Subpopulation of Astrocytes in Primary Cultures. Journal of Neuroscience Research, 52, 559-568. http://dx.doi.org/10.1002/(SICI) 1097-4547(19980601) 52:5<559::AID-JNR8>3.0.CO;2-B

[317] Takahashi, T and Suzuki, T. (2012) Role of Sulfatide in Normal and Pathological Cells and Tissues. Journal of Lipid Research, 53, 1437-1450. http://dx.doi.org/10.1194/jlr.R026682

[318] Zeng, Y and Han, X. (2008) Sulfatides Facilitate Apolipoprotein E-Mediated Amyloid- $\beta$ Peptideclearance through an Endocytotic Pathway. Journal of Neurochemistry, 106, 1275-1286. http://dx.doi.org/10.1111/j.1471-4159.2008.05481.x

[319] Buschard, K., Høy, M., Bokvist, K., Olsen, H.L., Madsbad, S., Fredman, P., et al. (2002) Sulphatide Controls Insulin Secretion by Modulation of ATP-Sensitive $\mathrm{K}^{+}$-Channel Activity and $\mathrm{Ca}^{2+}$-Dependent Exocytosis in Rat Pancreatic 
Beta-Cells. Diabetes, 51, 2514-2521. http://dx.doi.org/10.2337/diabetes.51.8.2514

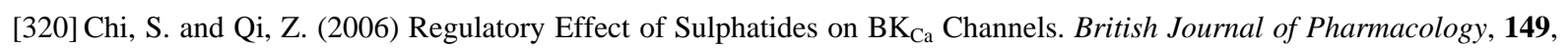
1031-1038. http://dx.doi.org/10.1038/sj.bjp.0706947

[321] Kim, W.T., Rioult, M.G. and Cornell-Bell, A.H. (1994) Glutamate-Induced Calcium Signaling in Astrocytes.Glia, 11, 173-184. http://dx.doi.org/10.1002/glia.440110211

[322] Yagi, K., Onaka, T. and Yoshida, A. (1998) Role of NMDA Receptors in the Emotional Memory Associated with Neuroendocrine Responses to Conditioned Fear Stimuli in the Rat. Neuroscience Research, 30, 279-286. http://dx.doi.org/10.1016/S0168-0102(98) 00008-X

[323] Talantovaa, M., Sanz-Blasco, S., Zhang, X., Xia, P., Akhtar, M.W., Okamoto, S., et al. (2013) A $\beta$ Induces Astrocytic Glutamate Release, Extrasynaptic NMDA Receptor Activation, and Synaptic Loss. Proceedings of the National Academy of Sciences of the United States of America, Early Edition.

[324] Parpura, V. and Haydon, P.G. (2000) Physiological Astrocytic Calcium Levels Stimulate Glutamate Release to Modulate Adjacent Neurons. Proceedings of the National Academy of Sciences of the United States of America, 97, 86298634. http://dx.doi.org/10.1073/pnas.97.15.8629

[325] Randal, R.B. and Thayer, S.A. (1992) Glutamate-Induced Calcium Transient Triggers Delayed Calcium Overload and Neurotoxicity in Rat Hippocampal Neurons. The Journal of Neuroscience, 12, 1882-1895.

[326] Lipton, S.A. and Nicotera, P. (1998) Calcium, Free Radicals and Excitotoxins in Neuronal Apoptosis. Cell Calcium, 23, 165-171. http://dx.doi.org/10.1016/S0143-4160(98) 90115-4

[327] Kessels, H.W., Nabavi, S. and Malinow, R. (2013) Metabotropic NMDA Receptor Function Is Required for $\beta$-Amyloid-Induced Synaptic Depression. Proceedings of the National Academy of Sciences of the United States of America, 110, 4033-4038.

[328] Zipfel, G.F. (2000) Neuronal Apoptosis after CNS Injury: The Roles of Glutamate and Calcium. Journal of Neurotrauma, 17, 857-869. http://dx.doi.org/10.1089/neu.2000.17.857

[329] Butche, A.J., Torrecilla, I., Young, K.W., Kong, K.C., Mistry, S.C., Bottrill, A.R., et al. (2009) N-Methyl-D-aspartate Receptors Mediate the Phosphorylation and Desensitization of Muscarinic Receptors in Cerebellar Granule Neurons. The Journal of Biological Chemistry, 284, 17147-17156. http://dx.doi.org/10.1074/jbc.M901031200

[330] Lu, W.Y., Xiong, Z.G., Lei, S., Orser, B.A., Dudek, E., Browning, M.D., et al. (1999) G-Protein-Coupled Receptors Act via Protein Kinase C and Src to Regulate NMDA Receptors. Nature Neuroscience, 2, 331-338. http://dx.doi.org/10.1038/7243

[331] Lee, F.S. (2003) Novel Crosstalk between G Protein-Coupled Receptors and NMDA Receptors. Experimental Neurology, 183, 269-272. http://dx.doi.org/10.1016/S0014-4886(03) 00249-8

[332] Qiu, Z., Crutcherb, K.A., Hymana, B.T. and Rebeck, G.W. (2003) ApoE Isoforms Affect Neuronal N-methyl-D-aspartate Calcium Responses and Toxicity via Receptor-Mediated Processes. Neuroscience, 122, 291-303. http://dx.doi.org/10.1016/j.neuroscience.2003.08.017

[333] Caruso, S., Agnello, C., Campo, M.G. and Nicoletti, F. (1993) Oxytocin Reduces the Activity of N-methyl-D-aspartate Receptors in Cultured Neurons. Journal of Endocrinology Investigation, 16, 921-924. http://dx.doi.org/10.1007/BF03348959

[334] Brayne, C., Gao, L. and Matthews, F. (2005) Challenges in the Epidemiological Investigation of the Relationships between Physical Activity, Obesity, Diabetes, Dementia and Depression. Neurobiology of Aging, 26, 6-10. http://dx.doi.org/10.1016/j.neurobiolaging.2005.09.030

[335] Convit, A. (2005) Links between Cognitive Impairment in Insulin Resistance: An Explanatory Model. Neurobiology of Aging, 26, 31-35. http://dx.doi.org/10.1016/j.neurobiolaging.2005.09.018

[336] Greenwood, C.E. and Winocur, G. (2005) High-Fat Diets, Insulin Resistance and Declining Cognitive Function. Neurobiology of Aging, 26, 42-45. http://dx.doi.org/10.1016/j.neurobiolaging.2005.08.017

[337] Brand-Miller, J., Hayne, S., Petocz, P. and Colagiuri, S. (2003) Low-Glycemic Index Diets in the Management of Diabetes: A Meta-Analysis of Randomized Controlled Trials. Diabetes Care, 26, 2261-2267. http://dx.doi.org/10.2337/diacare.26.8.2261

[338] Brand-Miller, J.C. (2003) Glycemic Load and Chronic Disease. Nutrition Reviews, 61, S49-S55. http://dx.doi.org/10.1301/nr.2003.may.S49-S55

[339] Dosunmu, R., Wu, J., Basha, R. and Zawia, N.H. (2007) Environmental and Dietary Risk Factors in Alzheimer’s Disease. Expert Review of Neurotherapeutics, 7, 887-900. http://dx.doi.org/10.1586/14737175.7.7.887

[340] Schiepers, O.J., de Groot, R.H.M., Jolles, J. van Boxtel, M.P.J. (2010) Fish Consumption, Not Fatty Acid Status, Is Related to Quality of Life in a Healthy Population. Prostaglandins, Leukotrienes and Essential Fatty Acids, 83, 31-35. http://dx.doi.org/10.1016/j.plefa.2010.02.030 
[341] Horrocks, L.A. and Farooqui, A.A. (2004) Docosahexaenoic Acid in the Diet: Its Importance in Maintenance and Restoration of Neural Membrane Function. Prostaglandins, Leukotrienes and Essential Fatty Acids, 70, 361-372. http://dx.doi.org/10.1016/j.plefa.2003.12.011

[342] Montuschi, P., Barnes, P. and Roberts2nd, L.J. (2007) Insights into Oxidative Stress: The Isoprostanes. Current Medicine Chemistry, 14, 703-717.

[343] Oster, T. and Pillot, T. (2010) Docosahexaenoic Acid and Synaptic Protection in Alzheimer's Disease Mice. Biochimica Biophysica Acta (BBA), Molecular and Cell Biology of Lipids, 1801, 791-798. http://dx.doi.org/10.1016/j.bbalip.2010.02.011

[344] Simopoulos, A.P. (2008) The Importance of the Omega-6/Omega-3 Fatty Acid Ratio in Cardiovascular Disease and Other Chronic Diseases. Experimental Biology Medicine (Maywood), 233, 674-688. http://dx.doi.org/10.3181/0711-MR-311

[345] Davidson, M.H. (2006) Mechanisms for the Hypotriglyceridemic Effect of Marine Omega-3 Fatty Acids. American Journal of Cardiology, 98, 27-33. http://dx.doi.org/10.1016/j.amjcard.2005.12.024

[346] Denechaud, P.D., Dentin, R., Girard, J. and Postic, C. (2008) Role of ChREBP in Hepatic Steatosis and Insulin Resistance. FEBS Letters, 582, 68-73. http://dx.doi.org/10.1016/j.febslet.2007.07.084

[347] Brisson, C.D. and Andrew, R.D. (2012) A Neuronal Population in Hypothalamus That Dramatically Resists Acute Ischemic Injury Compared to Neocortex. Journal of Neurophysiology, 108, 419-430.

[348] Radak, D., Resanovic, I. and Isenovic, E.R. (2013) Changes in Hypothalamus-Pituitary-Adrenal Axis Following Transient Ischemic Attack. Angiology, Epub Ahead of Print.

[349] Larsson, S.C, Orsini, N. and Wolk, A. (2013) Dietary Calcium Intake and Risk of Stroke: A Dose-Response Meta-Analysis. The American Journal of Clinical Nutrition, 97, 951-957. http://dx.doi.org/10.3945/ajcn.112.052449

[350] Li, K., Kaaks, R., Linseisen, J. and Rohrmann, S. (2012) Associations of Dietary Calcium Intake and Calcium Supplementation with Myocardial Infarction and Stroke Risk and Overall Cardiovascular Mortality in the Heidelberg Cohort of the European Prospective Investigation into Cancer and Nutrition Study (EPIC-Heidelberg). Heart, 98, 920-925. http://dx.doi.org/10.1136/heartjnl-2011-301345

[351] Heaney, R.P. and Barger-Lux, M.J. (1994) Low Calcium Intake: The Culprit in Many Chronic Diseases. Journal of Dairy Science, 77, 1155-1160. http://dx.doi.org/10.3168/jds.S0022-0302(94) 77052-1

[352] Nones, J., Stipursky, J., Costa, S.L. and Gomes, F.C.A. (2010) Flavonoids and Astrocytes Crosstalking: Implications for Brain Development and Pathology. Neurochemistry Research, 35, 955-996. http://dx.doi.org/10.1007/s11064-010-0144-0

[353] Sharma, V., Mishra, M., Ghosh, S., Tewari, R., Basu, A., Seth, P., et al. (2007) Modulation of Interleukin-1 $\beta$ Mediated Inflammatory Response in Human Astrocytes by Flavonoids: Implications in Neuroprotection. Brain Research Bulletin, 73, 55-63. http://dx.doi.org/10.1016/j.brainresbull.2007.01.016

[354] Silva, A.R., Pinheiro, A.M., Souza, C.S., Freitas, S.R.V.B., Vasconcellos, V., Freire, S.M., et al. (2008) The Flavonoid Rutin Induces Astrocyte and Microglia Activation and Regulates TNF-Alpha and NO Release in Primary Glial Cell Cultures. Cell Biology Toxicology, 24, 75-86. http://dx.doi.org/10.1007/s10565-007-9017-y

[355] Xu, S.L., Bi, C.W., Choi, R.C., Zhu, K.Y., Miernisha, A., Dong, T.T., et al. (2013) Flavonoids Induce the Synthesis and Secretion of Neurotrophic Factors in Cultured Rat Astrocytes: A Signaling Response Mediated by Estrogen Receptor. Evidence-Based Complementary and Alternative Medicine, 2013, Article ID127075.

[356] Martins, I.J. and Fernando, W.M.A.D.B. (2014) High Fibre Diets and Alzheimer's Disease.Food and Nutrition Sciences (Diet and Disease), 5, 410-424. http://dx.doi.org/10.4236/fns.2014.54049

[357] Ono, K., Yoshiike, Y., Takashima, A, Hasegawa, K., Naiki, H. and Yamada, M. (2003) Potent Anti-Amyloidogenic and Fibril-Destabilizing Effects of Polyphenols in Vitro: Implications for the Prevention and Therapeutics of Alzheimer's Disease. Journal of Neurochemistry, 87, 172-181. http://dx.doi.org/10.1046/j.1471-4159.2003.01976.x

[358] Choi, Y.J., Kim, T.D., Paik, S.R., Jeong, K.J. and Jung, S.H. (2008) Molecular Simulations for Anti-Amyloidogenic Effect of Flavonoid Myricetin Exerted against Alzheimer's $\beta$-Amyloid Fibrils Formation. Bulletin of the Korean Chemistry Society, 29, 1505-1509. http://dx.doi.org/10.5012/bkcs.2008.29.8.1505

[359] Hu, Y., Yang, Y., Yu, Y., Wen, G., Shang, N., Zhuang, W., et al. (2013) Synthesis and Identification of New Flavonoids Targeting Liver X Receptor $\beta$ Involved Pathway as Potential Facilitators of A $\beta$ Clearance with Reduced Lipid Accumulation. Journal of Medicinal Chemistry, 56, 6033-6053. http://dx.doi.org/10.1021/jm301913k

[360] Jin, C.H., Shin, E.J., Park, J.B., Jang, C.G., Li, Z., Kim, M.S., et al. (2009) Fustin Flavonoid Attenuates Beta-Amyloid (1-42) -Induced Learning Impairment. Journal of Neuroscience Research, 87, 3658-3670.

http://dx.doi.org/10.1002/jnr.22159

[361] Jadeja, R.N. and Devkar, R.V. (2014) Polyphenols in Human Health and Disease. Polyphenols in Chronic Diseases and 
their Mechanisms of Action. Chapter 47, Polyphenols and Flavonoids in Controlling Non-Alcoholic Steatohepatitis, 1, 615-623.

[362] Zhang, S., Zheng, L., Dong, D., Xu, L., Yin, L., Qi, Y., et al. (2013) Effects of Flavonoids from Rosa laevigata Michx Fruit against High-Fat Diet-Induced Non-Alcoholic Fatty Liver Disease in Rats. Food Chemistry, 141, 2108-2116. http://dx.doi.org/10.1016/j.foodchem.2013.05.019

[363] Phachonpai, W., Wattanathorn, J., Muchimapura, S., Tong-Un, T. and Preechagoon, D. (2010) Neuroprotective Effect of Quercetin Encapsulated Liposomes: A Novel Therapeutic Strategy against Alzheimer's Disease. American Journal of Applied Sciences, 7, 480-485. http://dx.doi.org/10.3844/ajassp.2010.480.485

[364] Cassidy, A., Rimm, E.B., O’Reilly, É.J., Logroscino, G., Kay, C., Chiuve, S.E., et al. (2012) Dietary Flavonoids and Risk of Stroke in Women. Stroke, 43, 946-951. http://dx.doi.org/10.1161/STROKEAHA.111.637835

[365] Sriraksa, N., Wattanathorn, J., Muchimapura, S., Tiamkao, S., Brown, K. and Chaisiwamongkol, K. (2012 ) CognitiveEnhancing Effect of Quercetin in a Rat Model of Parkinson’s Disease Induced by 6-Hydroxydopamine.Evidence-Based Complementary and Alternative Medicine, 2012, Article ID: 823206. http://dx.doi.org/10.1155/2012/823206

[366] Horáková, L. (2011) Flavonoids in Prevention of Diseases with Respect to Modulation of Ca-Pump Function. Interdisciplinary Toxicology, 4, 114-124. http://dx.doi.org/10.2478/v10102-011-0019-5

[367] van der Heide, D., Kastelijn, J. and Schröder-van der Elst, J.P. (2003) Flavonoids and Thyroid Disease. BioFactors, 19, 113-119. http://dx.doi.org/10.1002/biof.5520190303

[368] Santos, M.C., Gonçalves, C.F.L., Vaisman, M., Ferreira, A.C.F. and de Carvalho, D.P. (2011) Impact of Flavonoids on Thyroid Function. Food and Chemical Toxicology, 49, 2495-5012. http://dx.doi.org/10.1016/j.fct.2011.06.074

[369] Giuliani, C., et al. (2013) The Flavonoid Quercetin Inhibits Thyroid Function in Rats. Endocrinology Review, 34.

[370] Giuliani, C., Noguchi, Y., Harii, N., Napolitano, G., Tatone, D., Bucci, I., et al. (2008) The Flavonoid Quercetin Regulates Growth and Gene Expression in Rat FRTL-5 Thyroid Cells. Endocrinology, 149, 84-92. http://dx.doi.org/10.1210/en.2007-0618

[371] Soleas, G.J. (1998) Quercetin and p-Coumaric Acid Concentrations in Commercial Wines. American Journal of Enology and Viticulture, 49, 142-115.

[372] Squizzato A., Gerdes, V.E.A., Brandjes, D.P.M., Büller, H.R. and Stam, J. (2005) Thyroid Diseases and Cerebrovascular Disease. Stroke, 36, 2302-2310. http://dx.doi.org/10.1161/01.STR.0000181772.78492.07

[373] Baker, D.M. (2007) Thyroid Diseases and Stroke. In: Baker, D.M., Ed., Stroke Prevention in Clinical Practice, Springer, London, 113-114.

[374] Mafrica, F. and Fodale, V. (2008) Thyroid Function, Alzheimer’s Disease and Postoperative Cognitive Dysfunction: A Tale of Dangerous Liaisons? Journal of Alzheimer's Disease, 14, 95-105.

[375] Franco, M., Chávez, E. and Pérez-Méndez, O. (2011) Pleiotropic Effects of Thyroid Hormones: Learning from Hypothyroidism. Journal of Thyroid Research, 2011, Article ID: 321030. http://dx.doi.org/10.4061/2011/321030

[376] Davis, P.J., Davis, F.B. and Mousa, S.A. (2009) Thyroid Hormone-Induced Angiogenesis. Current Cardiology Review, 5, 12-16.

[377] Christmann, M. and Kaina, B. (2013) Transcriptional Regulation of Human DNA Repairgenes Following Genotoxic Stress: Trigger Mechanisms, Inducible Responses and Genotoxic Adaptation. Nucleic Acids Research, 41, 8403-8420. http://dx.doi.org/10.1093/nar/gkt635

[378] Jalili, M., Pati, S., Rath, B., Bjørklund, G. and Singh, R.B. (2013) Effect of Diet and Nutrients on Molecular Mechanism of Gene Expression Mediated by Nuclear Receptor and Epigenetic Modulation. The Open Nutraceuticals Journal, 6, 27-34.

[379] Pardee, K., Necakov, A.S. and Krause, H. (2011) Nuclear Receptors: Small Molecule Sensors That Coordinate Growth, Metabolism and Reproduction. Subcellular Biochemistry, 52, 123-153. http://dx.doi.org/10.1007/978-90-481-9069-0_6

[380] Petegnief, V. and Planas, A.M. (2013) SIRT1 Regulation Modulates Stroke Outcome. Translational Stroke Research, 4 , 663-671. http://dx.doi.org/10.1007/s12975-013-0277-y

[381] Clark, D., Tuor, U.I., Thompson, R., Institoris, A., Kulynych, A., Zhang, X., et al. (2012) Protection against Recurrent Stroke with Resveratrol: Endothelial Protection. PLoS ONE, 7, e47792. http://dx.doi.org/10.1371/journal.pone.0047792

[382] Brown, B.M., Peiffer, J.J., Sohrabi, H.R., Mondal, A., Gupta, V.B., Rainey-Smith, S.R., et al. (2012) Intense Physical Activity Is Associated with Cognitive Performance in the Elderly. Translational Psychiatry, 2, e191. http://dx.doi.org/10.1038/tp.2012.118 
Scientific Research Publishing (SCIRP) is one of the largest Open Access journal publishers. It is currently publishing more than 200 open access, online, peer-reviewed journals covering a wide range of academic disciplines. SCIRP serves the worldwide academic communities and contributes to the progress and application of science with its publication.

Other selected journals from SCIRP are listed as below. Submit your manuscript to us via either submit@scirp.org or Online Submission Portal.
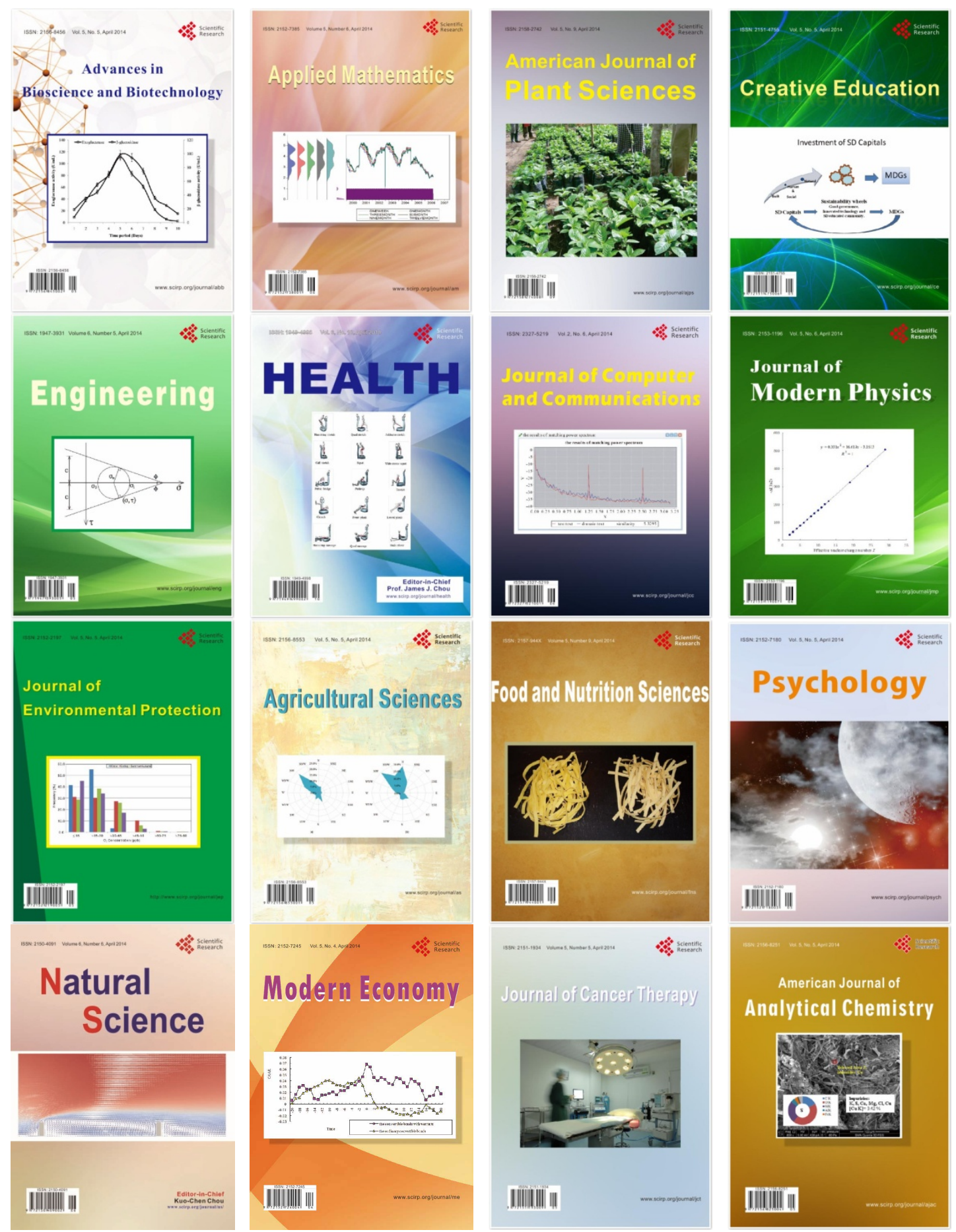